\title{
Numerical Prediction of the Seismic Behavior of Reassembled Columns in Ancient Structures: An Anastylosis Model for the Temple of Apollo Pythios in Gortyn (Crete)
}

\author{
Matteo Salvalaggio $^{1}\left(\mathbb{D}\right.$, Jacopo Bonetto ${ }^{1} \mathbb{D}$, Matteo Zampar ${ }^{2} \mathbb{D}$ and Maria Rosa Valluzzi ${ }^{1, *(\mathbb{D})}$ \\ 1 Department of Cultural Heritage, University of Padova, Piazza Capitaniato 7, 35139 Padova, Italy; \\ matteo.salvalaggio@unipd.it (M.S.); jacopo.bonetto@unipd.it (J.B.) \\ 2 Specialization School, University of Padova, piazza Capitaniato 7, 35139 Padova, Italy; \\ matteo.zampar@studenti.unipd.it \\ * Correspondence: mariarosa.valluzzi@unipd.it
}

check for updates

Citation: Salvalaggio, M.; Bonetto, J.; Zampar, M.; Valluzzi, M.R.

Numerical Prediction of the Seismic

Behavior of Reassembled Columns in Ancient Structures: An Anastylosis Model for the Temple of Apollo Pythios in Gortyn (Crete). Heritage 2021, 4, 3421-3441. https://doi.org/ $10.3390 /$ heritage 4040190

Academic Editor: Michele Betti

Received: 30 August 2021

Accepted: 11 October 2021

Published: 14 October 2021

Publisher's Note: MDPI stays neutral with regard to jurisdictional claims in published maps and institutional affiliations.

Copyright: (c) 2021 by the authors. Licensee MDPI, Basel, Switzerland. This article is an open access article distributed under the terms and conditions of the Creative Commons Attribution (CC BY) license (https:// creativecommons.org/licenses/by/ $4.0 /)$.

\begin{abstract}
The Temple of Apollo Pythios in Gortyn (Crete, Greece) dates back to the mid-7th century BC. The temple underwent several transformations and an ultimate destruction over time that resulted in the current remains of a Roman colonnade composed of six fragmented stone columns lying on the ground within the naos. In addition, the region was struck by several earthquakes which contributed to the various changes. The analysis of the fragments composing the column portions and their geometric features provided a possible outline for their standing repositioning. Based on the current seismic hazard of the region, a predictive numerical model of the colonnade in the anastylosis conditions suggested the need for proper connections between the fragments and the bases to ensure their overall conservation as a compound structure. The comparison of various configurations of intervention and the simple superimposition of the fragments also provided details on the accomplishment of minimal and compatible solutions.
\end{abstract}

Keywords: stone columns; Roman temple; anastylosis; numerical model; seismic behavior

\section{Introduction}

\subsection{Restoration of Archaeological Remains}

The preservation of cultural and architectural heritage is an aim and a challenging task for the scientific community, since this represents an inestimable treasure for society. The difficulties related to the conservation and restoration of cultural heritage are due to the high level of historical and technical knowledge required, the many unknowns related to material properties, the complex intervention methodology and the strict rules.

These issues are also deepened in the case of archaeological artifacts, which are usually found in an incomplete form and in a compromised conservation status.

The conservation of historical monuments and sites is also related to their use and visit from users, customers and tourists, who allow the interest towards this heritage to be kept alive. The access to archeological sites must be guaranteed in terms of safety for both the structures and people. In particular, this becomes a key factor when architectural remains are located in seismic-prone areas, as their vulnerability is further increased [1]. For this reason, structural interventions and restoration works need to be applied to the remains to achieve an equilibrium configuration and to improve the safety level. Their design needs special care and appropriate tools, within a solid methodology [2]. The historical background must be carefully recomposed and validated by onsite crosschecking to establish the bases on which suitable interventions can be designed.

Reference case studies can be found in Greece, due to the large number of archaeological sites that have been restored to meet current safety requirements. The principles described in the Venice Charter of 1964 governed the operations for the extensive restoration of the Athenian Acropolis from 1976 [3]. Stone elements were merged by threaded 
titanium bars. I-shaped clamps, based on metallic classical clamps, were designed for the Parthenon. Improved connections were also implemented for damaged and irregular groves by adding further transversal legs. The embedment of fasteners (i.e., titanium bars and clamps) within stone blocks was usually guaranteed by white cement paste [4]. Complementary elements were implemented only if necessary for the structural equilibrium, and, if they were used, they were differentiated from the ancient elements [5]. It is worth noting that the use of concrete repairs and steel connectors, as extensively applied during the 20th century to the Acropolis' monuments, led to further the decay and damage of stone elements, due to the high vulnerability of these modern materials to environmental attacks.

Since the 1990s, numerous restoration interventions of ancient temples and dry-stone structures have been conducted throughout Greece (e.g., Arcadian Bassai, Epidaurus, Nemea, Olympia, Messene, Lindos, Karthaia, Delos, Dodona) [4]. Today, virtual anastylosis is also applied to archaeological remains to allow visitors access to the immaterial form of ancient monuments [6,7].

The seismic simulation of archaeological remains and related restoration interventions is not an easy task, due to the many uncertainties regarding the material properties and conservation status and the onsite test limitations. Actually, while the structural assessment of modern structures is based on the evaluation of the strength of their components, archaeological remains are usually left in a condition where the structural material is in an advanced state of decay and is not able to provide significant resistance. Thus, the structural stability is mandated to equilibrium capacity based on the geometrical configuration and construction details. To face these issues, the usual tools applied to modern constructions are not suitable, and specific approaches must be followed.

The collapse of historic masonry structures has been discussed by the scientific community since the work of Heyman [8], which was one of the former attempts to unveil a different approach to unreinforced masonry structures than other construction systems. On that basis, both analytical and numerical tools addressed to the prediction of masonry equilibrium capacity have been validated. The former category includes the mathematical formulations for the simulation of block structures $[9,10]$. Recently, new equilibrium solutions have been provided, such as thrust network analysis [11], the no-compression membrane [12] and the extension of linear arch static analysis to masonry spiral stairs [13].

Numerical tools have also gained increasing popularity due to the increase of the computational capacity of calculators, allowing researchers to simulate and predict the behavior of complex and large structures. In particular, the Discrete Element Method (DEM) [14] and Non-Smooth Contact Dynamics (NSCD) [15] should be mentioned. Although originally addressed to granular materials and geotechnics, they have shown their capabilities in the simulation of masonry structures [16-19]. In particular, DEM has been largely used in the simulation of stone block masonry [20,21]. Application to historic [22] and archaeological $[23,24]$ structures has also proved to be effective in the seismic simulation of ancient remains.

The behavior of monolithic freestanding elements, such as some stone columns, relates to the rocking behavior of a single block $[25,26]$. DEM has proved to be particularly suitable for archaeological columns [27], whether monolithic or multi-drum. In particular, a 3D DEM code, Itasca 3DEC [28], has increased in popularity due to its ability to perform dynamic time-history analyses and to take into consideration material and geometric nonlinear properties, with the possibility of implementing either rigid or deformable blocks. Experimental tests and 3DEC numerical calibrations were carried out on a freestanding column specimen, allowing to the estimation of the properties that strongly affect the dynamic behavior of columns (e.g., joint interfaces, damping) [29]. Parametric studies within a 2D DEM environment (Itasca UDEC [30]) on the stability of classical columns (both monolithic and multi-drum) of the Temple of Apollo at Bassae and the Temple of Zeus at Nemea were discussed in [31], for different harmonic excitation frequencies and earthquake records. A performance-based seismic assessment with fragility curves of multidrum classical columns (i.e., a Parthenon's one) in a 3DEC environment was discussed 
in [32]. Parts of the Parthenon multi-drum columns were studied in a 3DEC environment by assessing the structural contribution of the architrave connected with clamps [33]. Further studies on these topics are published in $[34,35]$. DEM was also successfully applied to masonry aqueducts [36] and water towers [27,37]. Furthermore, effective simplified methods for the seismic assessment of freestanding columns were analyzed in [38-40]. Based on the large number of studies concerning the simulation of classical columns by means of DEM, the numerical analysis presented herein was carried out in the Itasca 3DEC 5.0 environment [41].

This work faces the issues of the partial reconstruction by anastylosis of the remains of the inner vertical supports of the Temple of Apollo Pythios in Gortyn (Crete, Greece), which is the focus of an ongoing research project carried out by the Italian Archaeological School of Athens and the University of Padova (Figure 1). A procedure aimed at bringing six columns back to their plausible ancient positions is presented, based on an integrated approach that complies with archaeological, restoration and engineering principles. Data collected onsite were used to classify and recollect the columns' remains, while the support of numerical predictions allowed the design of the structural devices that enable them to remain standing.

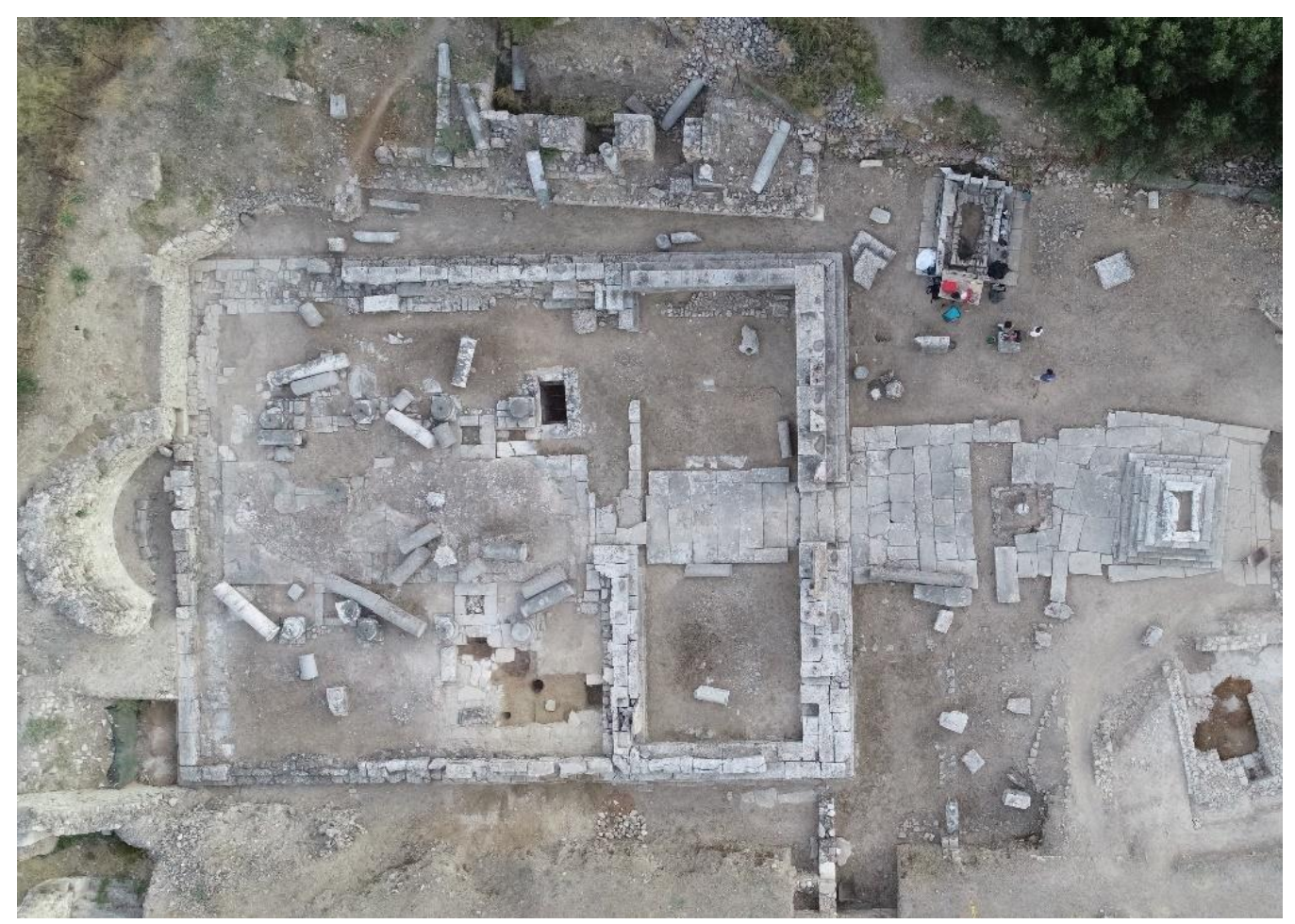

Figure 1. Remains of Temple of Apollo in Gortyn (Crete, Greece) in 2021.

\subsection{Gortyn and the Temple of Apollo}

The archaeological site of Gortyn extends to about 400 hectares (Figure 2) in the southcentral part of the island of Crete [42]. The first human presence in the area of the historic city dates back to the Neolithic age and was favored by the coexistence of a fertile plain and the protecting surrounding hills. 


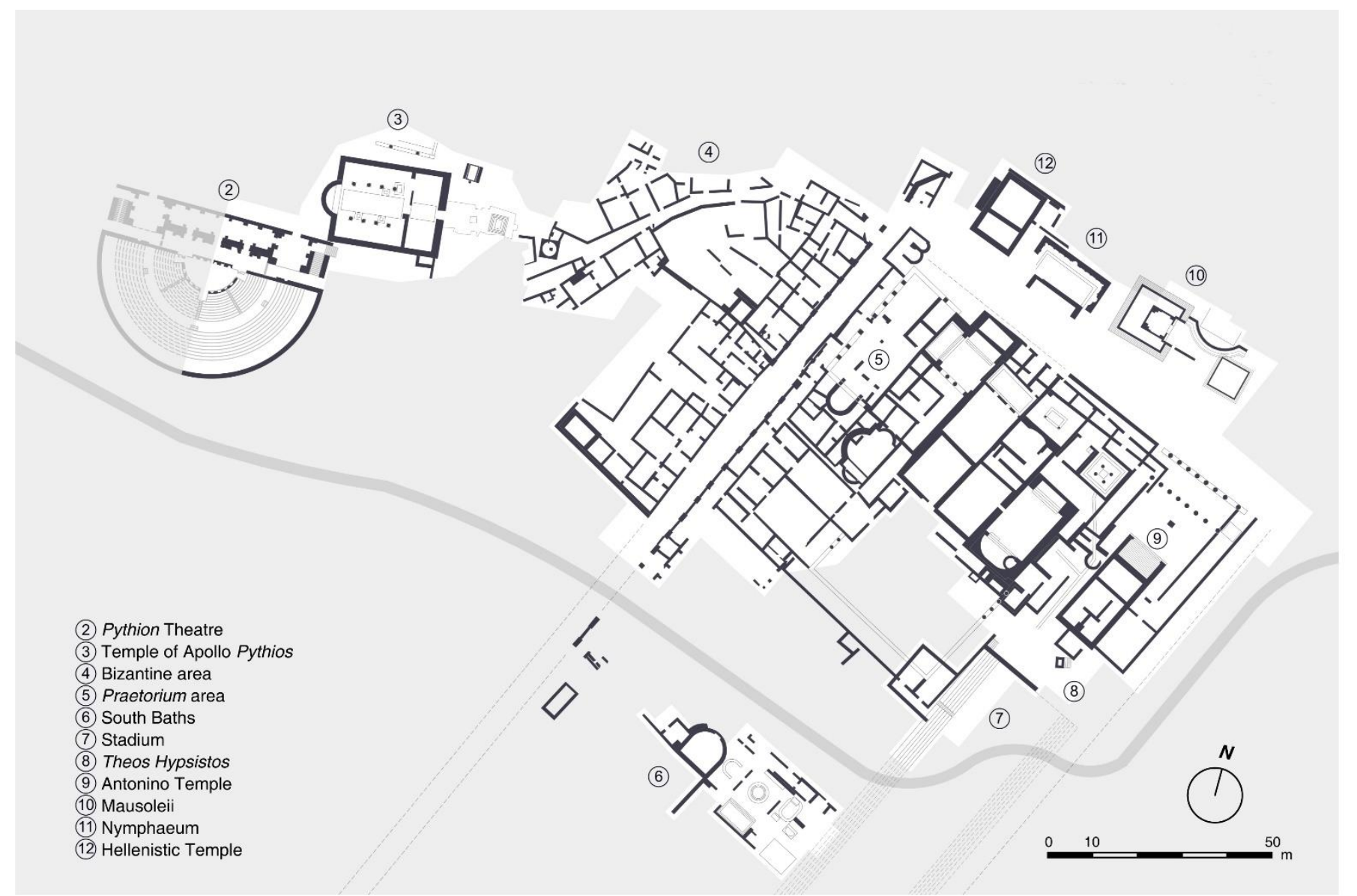

Figure 2. Plan of Gortyn archaeological site (adapted from image courtesy of V. De Scarpis).

The first known settlements in the area, however, date from the second half of the second millennium BC (Kannià), while the first occupation of the space of the future city took place in the transition phases between the second and first millennium BC. At that time, the first extensive villages were founded on the hills of Hagios Ioannis [43], Armi/Pervolopetra, Profitis Ilias [44] and Vourvoulitis [45], supported by an agricultural economy and a very well protected high-altitude position.

Since the Protogeometric period (ninth century BC), two sacred areas developed at the top of the Haghios Ioannis hill [42], the future acropolis of the city, and on the plain, where the Temple of Apollo Pythios would later rise [46]. The formation of these sanctuaries was strictly connected with the gradual development of an urban settlement between the eighth and seventh centuries $\mathrm{BC}$.

Although in use at the beginning of the first millennium BC, the sanctuary dedicated to Apollo Pythios was rearranged with the construction of the first building around the mid-7th century. Many hypotheses have been evaluated regarding the roof in this former phase, from its absence to a multi-pitched wooden roof $[47,48]$. However, according to more recent studies, the first construction would have been a large rectangular precint $\left(19.8 \times 17.65 \mathrm{~m}^{2}\right)$ that was unroofed, inside which open air ceremonies around an altar would have taken place. The building is based on a modulus of $33.3 \mathrm{~cm}$ and the use of multiples of six, which refers to the sexagesimal systems used mainly in the Middle East [49]. Of this first building, three foundation layers and the levelling course (euthynteria) are still present, sustaining two or three layers of squared blocks of the stepped platform that bare the law inscription of the archaic age.

Between the end of the seventh century and the beginning of the sixth century BC, the political body of the city was indeed well evident thanks to the laws inscribed on the walls of the Temple of Apollo [42]. 
After constant economic and political growth during the fifth century $\mathrm{BC}$, in the Hellenistic Age (fourth-second century BC), the influence of Gortyn over the whole of Crete increased, competing with Knossos, until it arrived at the head of the league of Cretan cities(kolvòv $\tau \widetilde{\omega} v K \rho \eta \tau \alpha \iota \varepsilon ́ \omega v)$. The urban plan of the city developed, with new fortifications [50] and the enhancement of public buildings (e.g., the reconstruction of heroon and the new construction of bouleterion) [50]. At the beginning of the third century $\mathrm{BC}$, the Temple of Apollo was enlarged by the addition of a pronaos in contact with the façade of the existing precint [51]. The new façade would have consisted of six Doric halfcolumns and a double-pitched roof with timber truss-beams covering the new structure. Near the Temple of Apollo, in the so-called area of the Praetorium, the Hellenistic Temple and the stadium were built [52] (Figure 2). Moreover, a new religious area was dedicated in Gortyn to the Egyptian Divinities, according to the important relationship with Ptolemaic dynasty from the early second century BC.

Crete was then conquered by the Roman consul Q. Caecilius Metellus in $67 \mathrm{BC}$, and the isle became a Roman pretorian provincia (with the Cyrenaica), within which Gortyn served as capital and (from $27 \mathrm{BC}$ onward) as a fixed administrative center for the aforementioned league of all the Cretan cities [53].

Under the Roman domination [48], the walls of the Temple of Apollo precint were partially demolished and reconstructed. Many blocks were reused in a random way, and thus the visibility of the ancient inscriptions was obstructed [54]. During the early imperial age, the naos was probably still unroofed. However, likely during the third century AD, the building underwent a radical transformation: the naos plan was modified with the addition of an apse on the west side and two niches in the north and south interior façades, and marble and granite columns were transferred from other city buildings and used to bear the timber truss-beams of the new roof $[47,48]$.

Between 295 and 297 AD, the isle of Crete was divided by Cyrenaica and inserted in the Moesia diocese ruled by a praeses. Constantine then promoted the island to Senath province in the diocese of Macedonia.

After the earthquake of $365 \mathrm{AD}$ [55] the Temple of Apollo collapsed, even if it cannot be excluded that the collapse of the building and its columns followed this event and could be connected to subsequent earthquakes. In the fourth and fifth century AD, some buildings arose in the temple area and were used until the final phase of the urban life.

Crete became finally part of the Eastern Roman Empire, until the Arab conquest in 827-828 AD [56].

\section{Materials and Methods}

\subsection{Bases of the Approach}

The anastylosis of archaeological remains is a delicate process, which should be based on a strict methodology for a reconstruction consistent with the ancient configuration and in compliance with restoration principles (an example of interventions on Greek ancient monuments is reported in [4]). In this work, a multi-disciplinary approach to support a possible reassembly by anastylosis of the stone columns of the ancient Temple of Apollo Pythios in Gortyn is proposed, according to the following steps:

1. Information about the historical urban development and seismicity of the Gortyn area were collected and crosschecked with onsite surveys. Hence, an extensive study of current reconstruction techniques used in Greek monuments was carried out. These usually consist of multi-drum stone columns, to which the columns studied in this paper could be preliminarily assimilated due to their condition after collapse. Analyses and interventions carried out by other authors demonstrated that the key factor of this structural type relies on the connections between drums.

2. The current remains of the site were analyzed based on existing digital $2 \mathrm{D}$ and $3 \mathrm{D}$ plans and recent photographic surveys. The cataloging of the information was carried out based on (i) the dimensions of fragments (i.e., length and diameters), (ii) materials, (iii) connection traces (e.g., central dowels holes and pins-in the case of 
the columns made by pieces or drums, the connections between them were made by specific metallic and wooden elements called empolion and polos) and (iv) the ancient configuration of the column (i.e., multi-element or monolithic at the time of the last earthquake, which made the Temple of Apollo collapse).

3. The current layout of the remains was shaped within a geometrical 3D CAD model. The repositioning phase permitted us to (i) check if structural parts were lost, (ii) deduce some missing measurements and (iii) provide a geometric model for the structural assessment.

4. Structural materials for supporting the anastylosis design were identified, among those usually implemented for conservation. In accordance with restoration principles and materials applied within restored areas in Greece, connectors and binders that can be easily removable and compatible with ancient stone (e.g., rustproof) were preferred. Grouted titanium connectors were therefore chosen, and their design characteristics were calculated.

5. The anastylosis intervention on columns needs to be assessed from a seismic point of view, since Gortyn is a seismic-prone area (see Section 2.3) [57]. The geometric model was imported into the structural modeling tool (i.e., Itasca 3DEC [41]) where various intervention configurations were analyzed. Dynamic time-history analyses were carried out, with velocigrams deduced by the site seismic spectrum. An incremental procedure was applied by increasing the number and size of connectors from zero (simple superposition of blocks with no connectors) to the total number of interfaces among blocks. The procedure was completed when a safe configuration was detected.

\subsection{Remains of the Temple of Apollo}

The archaeological research that has been carried out since 2013 by the University of Padova and the review of the conspicuous epigraphic material already known from the 19th century excavations $[54,58]$ shed new light on the long life of the sacred area of the Temple of Apollo Pythios [46,49,51,59-61].

Within the naos, eight column bases are preserved, while the fragments of six out of eight stone columns lie on the ground (Figure $3 a$ ). The two missing columns were probably removed for reuse on other worksites, as frequently practiced during late antiquity or the Middle Ages. Both orthogonal and inclined failure planes were detected on the fragment ends. All of the top elements of the six columns show dowel holes (both circular and rectangular), which were probably used to fasten the capitals (Figure $3 b, c)$, while four out of the six base fragments have holes on their bottom face (Figure 3d). Some columns also show holes in the central part of the shaft, which were probably used in previous interventions after earthquake shocks. The remains were divided by stone type (marble or granite) and ancient configuration (multi-element or monolithic).

The complete analysis and cataloging of the fragments is reported in Section 3.1.

\subsection{Seismic Background and Classification}

The Mediterranean area has been struck by many earthquakes and tsunami throughout human history, and many witness accounts are collected in documents and archaeological remains. As regards the island of Crete, several seismic and sea-wave events occurred from ancient times to the 15th century $[62,63]$.

The first historically known earthquake involved Knossos and Leben, but its dating is still unclear. Di Vita dated it in $46 \mathrm{AD}$ [64], although recent studies placed it among 53, 62 or $66 \mathrm{AD}$ [62]. The main proof of this seismic event is in the Vita Apollonii by Flavius Philostratus (Philostr. V. Apo 4.34). Apollonius was in Leben, and the earthquake hit the entire island while the sea receded about seven stades [62]. 
According to many literary sources (Ammianus Marcellinus 26.10.15-19) and archaeological evidence, on the 21st of July $365 \mathrm{AD}$, an earthquake occurred and caused a tsunami that involved the mouth of the Nile and the coasts of Dalmatia, Sicily and Greece [62]. In particular, an eight-meter uplift occurred in the southern and western parts of the island (Phalasarna headland) [65], which placed the epicenter in the central part of Crete. The destructive effects of the shocks were recorded not only on the isle but also in other Mediterranean regions, although many events may have occurred before and after $365 \mathrm{AD}$ and may have been linked to that date. Certainly, in Gortyn, many important structures collapsed in $365 \mathrm{AD}$, including the theatre close to the Temple of Apollo. Further details about this event are discussed in [66], where a seismic magnitude Mw higher than 8.5 was computed for the uplift of Crete. However, Gortyn rapidly recovered, thanks to its solid political background. After the 365 AD shocks, among others, the buildings of the Praetorium were reconstructed, such as the baths, according to Di Vita, 1996 [64]. However, Malalas (Mal. 359) reports that in the reign of Theodosius II, a different earthquake (408-450 AD) caused the public baths to collapse.

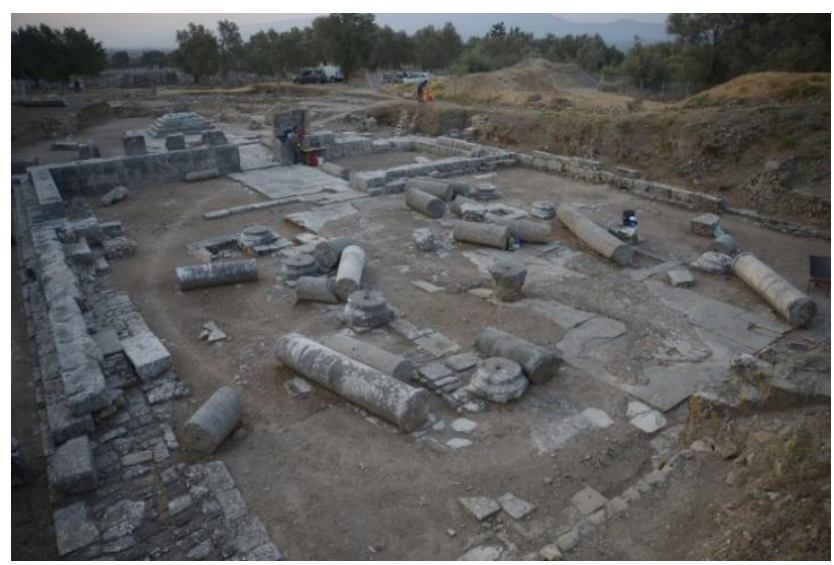

(a)

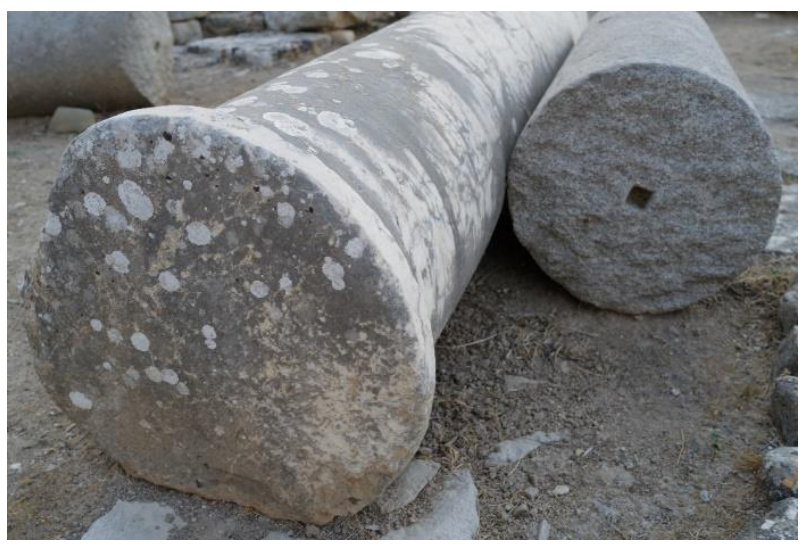

(c)

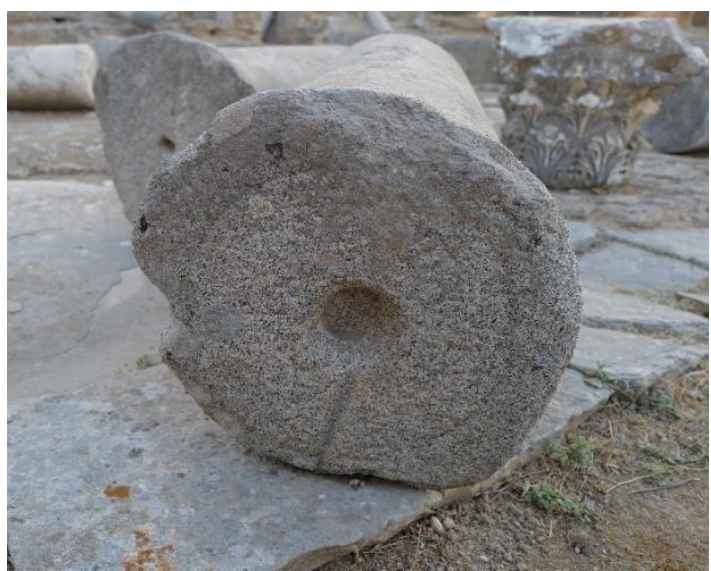

(b)

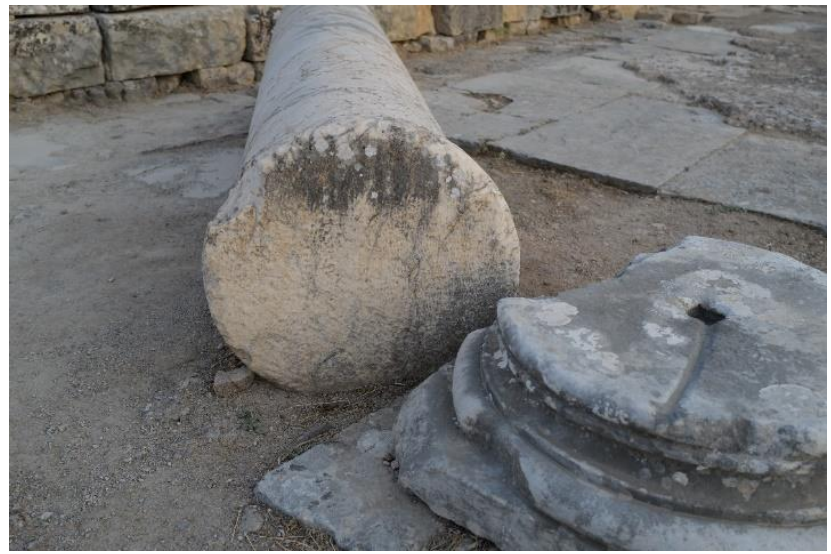

(d)

Figure 3. (a) Current configuration of colonnade remains; detail of element interface of (b) top element of C2 (i.e., C2.4 element in front; C4.1 bottom element behind), (c) bottom element of C5 (C5.1, left) and inner element of C2 (C.2.3, right), (d) bottom element of C6 (C6.1) and base block of C4 (B4).

A new, violent seismic shock occurred in $670 \mathrm{AD}$ and threatened the integrity of a large part of the urban landscape; this event started a phase of decline, although the city resisted against it until the beginning of the ninth century AD [66]. In April 796 AD, according to Theophanes (Theoph. 470), a violent earthquake struck Crete during the celebration of the marriage between the emperor and Theodote [62]. 
After the end of ancient Gortyn, under the Venetian dominion of Crete, on the eighth of August 1303, a seismic event of about $8 \mathrm{Mw}$ with its epicenter in Crete occurred again in the Mediterranean area, involving a tsunami, the flooding of the Nile river and landslides [63]. The most severe damage was recorded in the capital of Crete, Candia (now Iraklion), and in the surrounding area, where many castles collapsed (under a macroseismic level of $X$ degree, according to the Mercalli-Cancani-Sieberg scale). Damage was recorded in Egypt, Greece, Jordan, Israel, Syria and Turkey. The tsunami affected Candia in Crete, Acre in Israel and Alexandria in Egypt [63]. Arab literature information is also recollected in [67].

On 1 July 1494, two seismic shocks (MCS macroseismic degrees VIII and V) occurred in Candia, which caused severe damage to bell towers, churches and houses [63]. The information was collected in the diary of Pietro Casola, an Italian priest on a pilgrimage to Jerusalem.

The current seismic hazard of Gortyn can now be derived from Eurocode 8 [68] and the Greek seismic building code EAK-2000/2003 [69]. Three seismic zones are assigned: Crete belongs to zone II, where the expected Peak Ground Acceleration (PGA), with a 10\% probability of exceedance in 50 years (i.e., average return period of 475 years), is $0.24 \mathrm{~g}$. Soil category C (i.e., deep deposits of dense or medium-dense sand, gravel or stiff clay) is assumed for the site, in accordance with an analysis carried out in the near theatre [57], which implies a soil factor $S$ equal to 1.2. Figure 4a shows the elastic response spectrum $\mathrm{S}_{\mathrm{e}}(\mathrm{T})$, for a damping correction $\eta=1$, according to the site features. Based on this elastic spectrum, eight $25 \mathrm{~s}$ artificial seismic time histories (i.e., velocigrams) were derived from the SeismoArtif tool [70] and then used as an input for the DEM analysis of the columns (Figure 4b) (see Section 3.4).

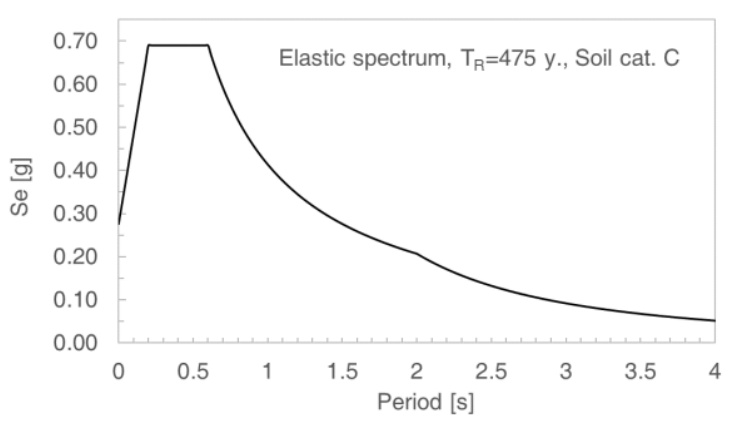

(a)

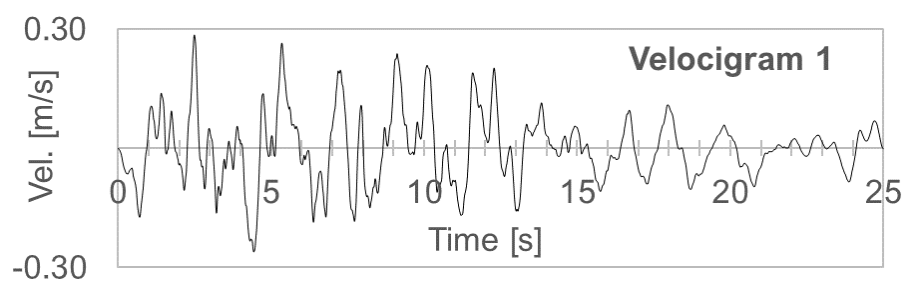

(b)

Figure 4. (a) Elastic spectrum of Gortyn according to Eurocode 8 [68]; (b) example of velocigram applied to DEM analysis.

\subsection{Structural Materials and Reassembly Design}

According to [4,71], titanium is the most suitable material for connectors within ancient monuments, since it is resistant to all types of corrosion and it has a high strength with low weight, a low coefficient of thermal expansion and a high failure elongation (about 20\%). These properties are suitable for archaeological remains, which are commonly exposed to natural phenomena such as rain (which could cause corrosion) and a high temperature range (which affects the deformation of metallic elements), which could damage the ancient material to which they are bonded. High failure elongation allows the components to undergo large displacements before collapse.

For the anastylosis proposal of the Temple of Apollo, ASTM B348 Grade 2 titanium fasteners [72] were selected (Table 1). 
Table 1. Properties of titanium connectors (density $\rho$, Young's modulus E, Poisson ratio $v$, yielding $f_{y}$ and ultimate strength $\mathrm{f}_{\mathrm{u}}$ ) [72].

\begin{tabular}{cc}
\hline \multicolumn{2}{c}{ ASTM B348 Grade 2 Titanium Properties } \\
\hline$\rho\left(\mathrm{kg} / \mathrm{m}^{3}\right)$ & 4510 \\
$\mathrm{E}(\mathrm{MPa})$ & 105,000 \\
$\nu(-)$ & 0.32 \\
$\mathrm{f}_{\mathrm{y}}(\mathrm{MPa})$ & 275 \\
$\mathrm{f}_{\mathrm{u}}(\mathrm{MPa})$ & 345 \\
\hline
\end{tabular}

Titanium fasteners have been designed for ancient monuments and tested by various authors. Papadopoulos and Vintzileou [71] discussed the testing and simulations of titanium poles shaped on the basis of ancient empolia-pole systems. These elements were employed for multi-drum stone columns and were shaped to bear shear forces. Nevertheless, the fragmented columns of the Temple of Apollo are slightly different from classical multi-drum columns, which are properly designed as stacked blocks. The fragments found in Gortyn are slender, in contrast to classical squat drums, and their behavior is ruled by a sum of sliding, rocking and wobbling [73]. Since rocking and wobbling are expected to be dominant over sliding for slender blocks, traditional bar elements were chosen for the connection of the fragments, meaning that the axial stiffness and strength could be activated in addition to shear ones. For this purpose, the embedment of connectors within the stone blocks is crucial. Pull-out tests of threaded titanium bars from marble blocks are reported in [74]. Circular bars, $11 \mathrm{~mm}$ wide and $75 \mathrm{~mm}$ long embedded with white cement paste, were extracted from marble blocks. Failure occurred at the binder-marble interface with a peak pull-out force of about $30 \mathrm{kN}$, which corresponds to an interface tangential stress of about $11 \mathrm{MPa}$. A dynamic simulation of the reinforced classical columns through DEM is described in [73], where the marble-cement interface behavior was assessed by experimental tests.

An M5-category lime-cement paste [75] (Young's modulus $\mathrm{E}_{\mathrm{g}}=8000 \mathrm{MPa}$ and shear modulus $\mathrm{G}_{\mathrm{g}}=3400 \mathrm{MPa}$ ) was chosen to embed the threaded titanium fasteners into the fragments of the Temple of Apollo to obtain a conservative estimation of the connectors' capacity. The behavior of connections can be simulated through the laws reported in [41] and successfully used in [76]. The axial and shear stiffnesses $K_{\mathrm{a}}$ and $K_{\mathrm{s}}$ were calculated according to Equations (1) and (2), respectively:

$$
\begin{gathered}
K_{a}=\pi k d_{1} \\
K_{s}=E_{b} I \beta^{3}
\end{gathered}
$$

where

$$
\begin{gathered}
k=\sqrt{\left[\frac{\frac{1}{2} G_{g} E_{b}}{\frac{d_{2}}{d_{1}}-1}\right]} \\
\beta=\sqrt[4]{K /\left(4 E_{b} I\right)} \\
K=2 E_{g} /\left(\frac{d_{2}}{d_{1}}-1\right)
\end{gathered}
$$

where $d_{1}$ is the diameter of the titanium connector, $d_{2}$ is the diameter of the connector's hole, $G_{g}$ is the binder's shear modulus, $E_{b}$ is the Young's modulus of the connector, and I is the second moment of inertia of the connector.

The ultimate axial and shear strengths $P_{u l t}$ and $F_{s, b}^{m a x}$ were calculated, according to [41], as

$$
P_{u l t}=0.1 \sigma_{c} \pi d_{2} L
$$




$$
F_{s, b}^{\max }=0.67 d_{1}^{2} \sqrt{\left(\sigma_{b} \sigma_{c}\right)}
$$

where $\sigma_{c}$ is the compression strength of stone (i.e., marble or granite, see Section 3.1), $\sigma_{b}$ is the yielding strength of the connector, and $L$ its bond length. The connections must be designed so that the rupture of the titanium bar occurs at higher forces than the stonebinder interface failure, taking into account the interfaces' ultimate stresses, as determined in [74].

Granite density $\rho$ and compressive behavior $\mathrm{f}_{\mathrm{c}}$ were taken from [77], while the normal and shear stiffnesses of joints $\left(\mathrm{j}_{\mathrm{kn}}\right.$ and $\left.\mathrm{j}_{\mathrm{ks}}\right)$ and friction angle $\varphi$ were taken from $[38,78]$. Zero cohesion $\mathrm{c}$ and tensile strength $\mathrm{f}_{\mathrm{t}}$ were assumed. Table 2 lists the properties of the stone element blocks and interfaces. In the absence of experimental investigations on stone materials, properties of marble elements were assumed to be comparable to granite, according to tests discussed in [77].

Table 2. Properties of DE model elements and interfaces.

\begin{tabular}{ccc}
\hline \multicolumn{3}{c}{ Stone Block Properties } \\
\hline$\rho\left(\mathrm{kg} / \mathrm{m}^{3}\right)$ & & 2750 \\
$\mathrm{f}_{\mathrm{c}}(\mathrm{MPa})$ & & 42 \\
\hline & Joint properties & $5 \times 10^{11}$ \\
$\mathrm{j}_{\mathrm{kn}}(\mathrm{Pa} / \mathrm{m})$ & & $5 \times 10^{11}$ \\
$\mathrm{j}_{\mathrm{ks}}(\mathrm{Pa} / \mathrm{m})$ & 0.63 \\
$\tan \varphi(-)$ & 0 \\
$c\left(\mathrm{~N} / \mathrm{m}^{2}\right)$ & 0 \\
$\mathrm{f}_{\mathrm{t}}\left(\mathrm{N} / \mathrm{m}^{2}\right)$ & & 0 \\
\hline
\end{tabular}

\section{Results}

\subsection{Geometrical and Material Features of the Columns}

The current pattern of the fragmented elements detected in the Temple of Apollo allowed the possible ancient layout of six standing columns to be recomposed. The essential hypotheses and assumptions for the digital anastylosis, which served as a reference model for the DEM simulation, are discussed in Section 3.2.

Based on an extensive onsite survey of the fragments, stone types and ancient connection evidence (e.g., dowel holes) were identified (although some doubts still exist regarding the type of marble of columns No. 3, 5, 6, according to [47,48,79]). Data were recollected in tabular (Table 3) and geometric (Figure 5) forms. Hole details among inner fragment surfaces provided information about the status of columns at the last destructive earthquake; i.e., if they were multi-element columns (as for $\mathrm{C} 1, \mathrm{C} 2, \mathrm{C} 4)$ or monolithic $(\mathrm{C} 3, \mathrm{C} 5$, C6). Dowel holes are also present in the column bases, except for the eastern couple (B1, B5) (see also Figure 3 for details). On average, holes were up to $3-5 \mathrm{~cm}$ deep. 
Table 3. Geometric, material and connection data of remains of Temple of Apollo.

\begin{tabular}{|c|c|c|c|c|c|c|}
\hline $\begin{array}{l}\text { Column and } \\
\text { Fragments Code }\end{array}$ & Height (m) & $\begin{array}{c}\text { Bottom } \\
\text { Diameter (m) }\end{array}$ & $\begin{array}{c}\text { Middle } \\
\text { Diameter (m) }\end{array}$ & $\begin{array}{c}\text { Top Diameter } \\
(\mathrm{m})\end{array}$ & Stone Type & $\begin{array}{l}\text { Connection Traces on } \\
\text { Column Ends }(\mathrm{cm})\end{array}$ \\
\hline Column 1 & 4.73 & 0.654 & & 0.593 & \multirow{4}{*}{ Grey granite } & \multirow{4}{*}{$\begin{array}{l}\text { Bottom }(4.9 \times 4.6) \\
\text { Top }(7.0 \times 8.0)\end{array}$} \\
\hline 1.1 & 1.93 & 0.654 & 0.619 & 0.586 & & \\
\hline 1.2 & 1.94 & 0.597 & 0.569 & 0.543 & & \\
\hline 1.3 & 0.84 & 0.541 & 0.568 & 0.595 & & \\
\hline Column 2 & 4.65 & 0.645 & & 0.542 & \multirow{5}{*}{ Grey granite } & \multirow{5}{*}{$\begin{array}{c}\text { Bottom }(5.2 \times 4.6) \\
\text { Top }(9.8 \times 9.0)\end{array}$} \\
\hline 2.1 & 0.754 & 0.645 & 0.613 & 0.585 & & \\
\hline 2.2 & 0.881 & 0.568 & 0.551 & 0.533 & & \\
\hline 2.3 & 1.485 & 0.506 & 0.512 & 0.518 & & \\
\hline 2.4 & 1.497 & 0.547 & 0.544 & 0.542 & & \\
\hline Column 3 & 4.75 & 0.649 & & 0.506 & \multirow{4}{*}{$\begin{array}{l}\text { Proconnesus } \\
\text { marble }\end{array}$} & \multirow{4}{*}{$\begin{array}{c}\text { Bottom }(*) \\
\text { Top }(5.6 \times 5.7)\end{array}$} \\
\hline 3.1 & 1.374 & 0.649 & 0.631 & 0.617 & & \\
\hline 3.2 & 2.048 & 0.590 & 0.561 & 0.534 & & \\
\hline 3.3 & 1.375 & 0.561 & 0.535 & 0.506 & & \\
\hline Column 4 & 4.57 & 0.549 & & 0.50 & \multirow{5}{*}{ Grey granite } & \multirow{5}{*}{$\begin{array}{l}\text { Bottom }(5.2 \times 5.1) \\
\quad \text { Top }(6.4 \times 7.1)\end{array}$} \\
\hline 4.1 & 1.5 & 0.549 & 0.555 & 0.56 & & \\
\hline 4.2 & 0.82 & 0.56 & 0.550 & 0.54 & & \\
\hline 4.3 & 1.49 & 0.54 & 0.525 & 0.51 & & \\
\hline 4.4 & 0.83 & 0.51 & 0.505 & 0.50 & & \\
\hline Column 5 & 4.68 & 0.604 & 0.574 & 0.544 & \multirow{3}{*}{ Portasanta marble } & \multirow{3}{*}{$\begin{array}{c}\text { Bottom (-) } \\
\text { Top }(5.4 \times 5.6)\end{array}$} \\
\hline 5.1 & 2.853 & 0.604 & 0.575 & 0.547 & & \\
\hline 5.2 & 1.745 & 0.531 & 0.537 & 0.544 & & \\
\hline Column 6 & 4.50 & 0.632 & & 0.575 & \multirow{3}{*}{ Portasanta marble } & \multirow{3}{*}{$\begin{array}{c}\text { Bottom }(-) \\
\text { Top }(5.7 \times 5.2)\end{array}$} \\
\hline 6.1 & 2.720 & 0.632 & 0.593 & 0.550 & & \\
\hline 6.2 & 1.875 & 0.537 & 0.556 & 0.575 & & \\
\hline
\end{tabular}

* Not measurable owing to damage. - No hole (flat base).

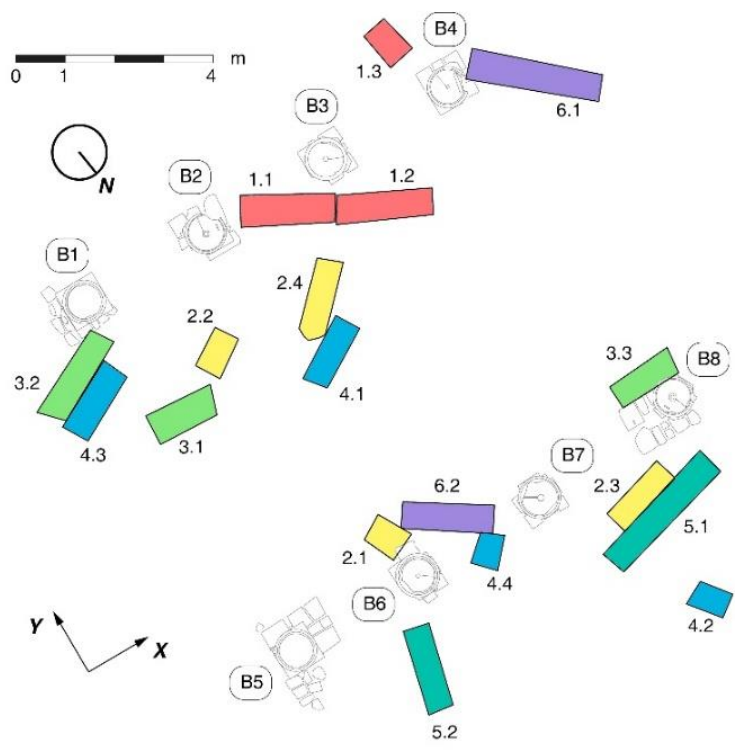

(a)

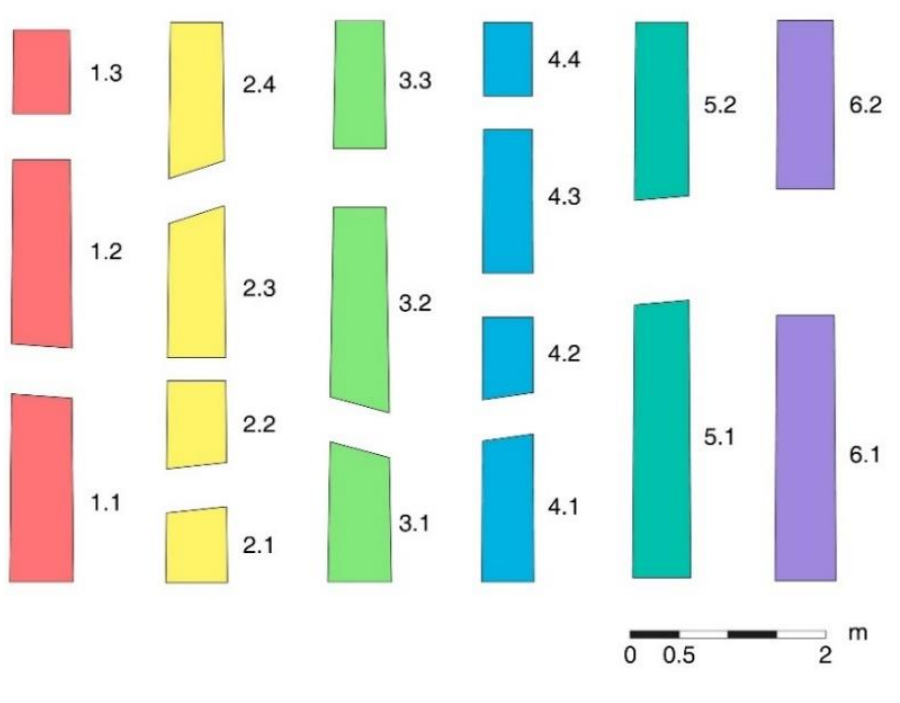

(b)

Figure 5. (a) Outline of top view of Temple of Apollo remains; (b) geometrical rearrangement of fragments into six columns (BX base code, X.X column's fragment code).

\subsection{Digital Anastylosis}

The 3D digital reconstruction of the six columns was necessary to implement the numerical model and perform the seismic simulations. 
Owing to the conditions of the remains and the lack of reliable information on the ancient aspect of the temple, the model needed to be completed based on the following hypotheses:

- Most of the fragments of the six columns are present in the site and modeled, while minor lacks are filled with compatible paste;

- Columns were formerly arranged into couples with similar elements (i.e., with respect to dimensions and materials);

- $\quad$ The two rows of columns had a symmetrical layout (i.e., shape and material are considered similar for facing columns);

- $\quad$ The current positions of some of the remains are similar to the found positions (i.e., no adjustment was done after collapse);

- Columns fragments can be derived from the reuse of remains of other structures;

- Interfaces of elements are flattened with respect to the possible real uneven condition.

These assumptions are needed to provide at least one of the plausible solutions for the anastylosis and assess its structural safety (one should consider that if the assumptions change, the results need to be updated). Therefore, the columns C1 and C4, C5 and C6, being similar to each other, are supposed to be two coupled pairs; columns C2 and C3 have different characteristics, meaning that they are supposed to belong to two different couples and to have lost their facing symmetrical ones.

Figure 6 shows the 3D digital reconstruction of the columns of the Temple of Apollo.

\subsection{DEM Modeling}

The numerical model was implemented within Itasca 3DEC [41] (Figure 7). The columns were discretized through rigid blocks with Coulomb interfaces between them, where all nonlinearities were lumped. Since concave and circular elements are not allowed in 3DEC, a meshing procedure was applied to the columns in order to approximate them with multi-faceted prisms. Besides, the bases underneath the columns were not modeled due to the peculiar concavities generated by the advanced decay, which could not be translated into the numerical code. During post-processing, a displacement limit is given by the base dimensions; i.e., if the column centroids overcome their base shape during an earthquake, the elements are considered unstable and the configuration unsafe. The connectors were simulated through axial reinforcement elements (see Section 2.4) with axial and shear stiffnesses and strengths. No capitols were modeled since their collocation is still uncertain. 


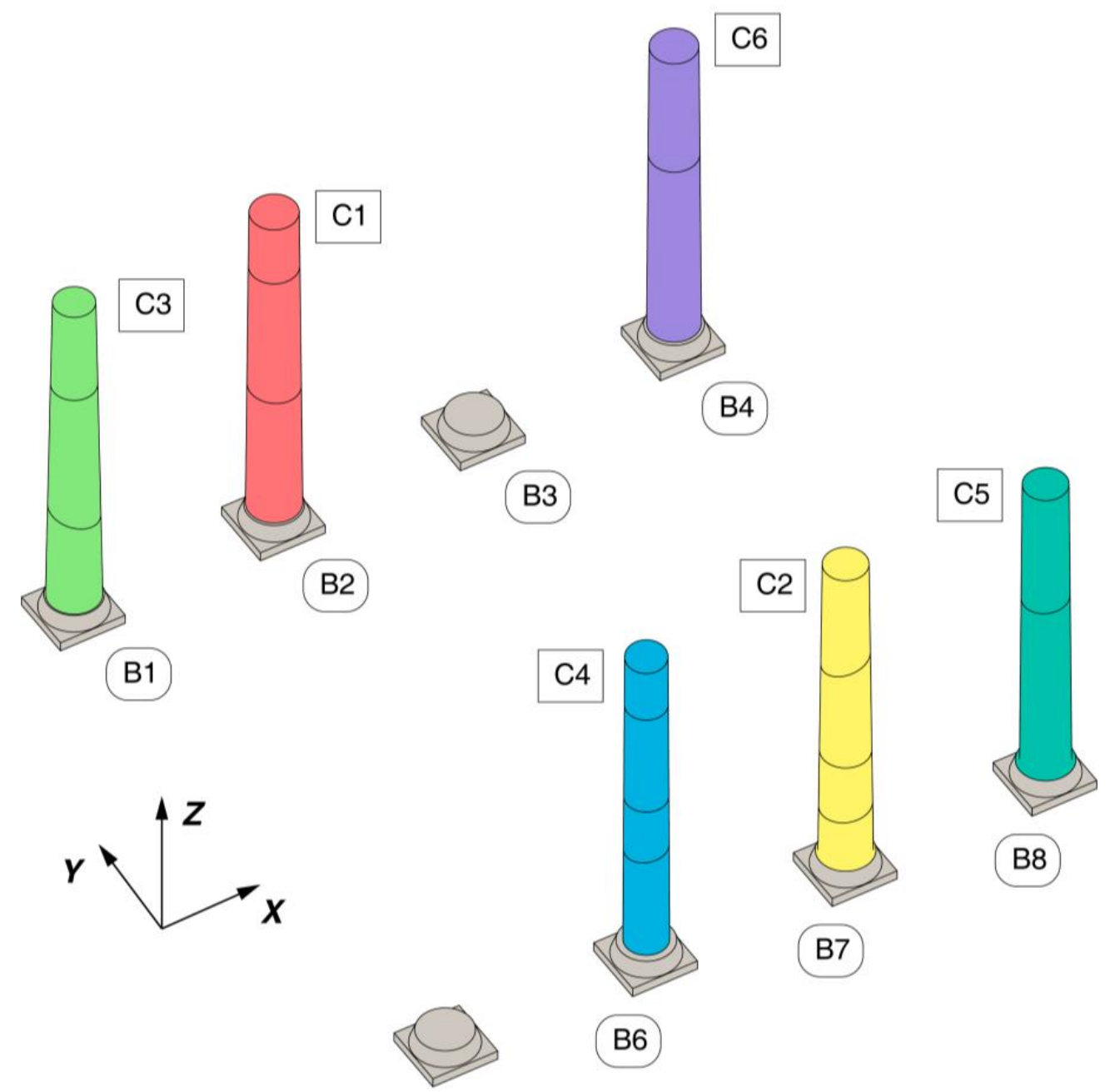

B5

Figure 6. Digital anastylosis of columns of Temple of Apollo (BX base code, CX column code).

A pair of velocigram time-histories was assigned to the ground block along the two main horizontal directions, $X$ and $Y$. Dynamic analyses were performed assuming zero viscous damping [29] and joint friction for seismic energy dissipation. According to [68], each model configuration is considered safe if it can stand at least four analyses without failure. Thus, four couples of time-histories were applied to each model.

The models were assessed by an incremental procedure, from the simple superimposition of fragments (i.e., "minimum intervention") until the achievement of the condition able to bear the expected seismic forces. Four simulations were carried out, according to the following intervention scenarios and corresponding models:

A. No connections between fragments or to the base block (Figure 7a). This configuration consists of a simple assemblage and superposition of the collapsed elements. Since inclined joints are present, the reassembled columns are not expected to stand in equilibrium.

B. Grouted threaded titanium bars ( $16 \mathrm{~mm} \varnothing$ and $200 \mathrm{~mm}$ long) between fragments and no connection to the base block (Figure $7 \mathrm{~b}$ ). The columns are reassembled and free to rock around base hinges. Since no paste is inserted between mutual surfaces, some energy dissipation is provided by the friction and opening of joints.

C. Grouted threaded titanium bars $(16 \mathrm{~mm} \varnothing$ and $200 \mathrm{~mm}$ long) between fragments and connection to the base block (Figure 7c). This configuration includes connectors at the base block-ground interface, with the same $200 \mathrm{~mm}$ bars as above. In this case, 
resisting forces are expected to increase in the titanium bars, particularly towards the base.

D. Grouted threaded titanium bars (32 $\mathrm{mm} \varnothing$ and $400 \mathrm{~mm}$ long) between fragments and connection to the base block (Figure 7d). This configuration has the same layout as model $\mathrm{C}$ but has double-sized connectors in both diameter and length.
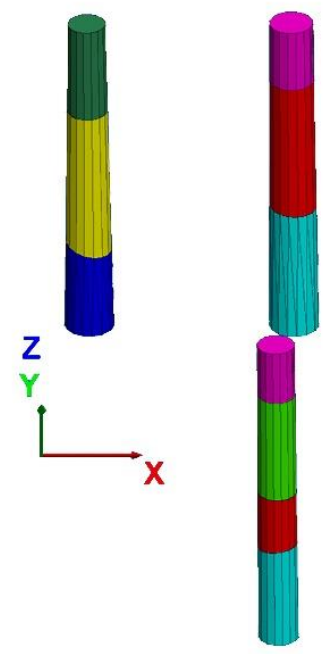

(a)

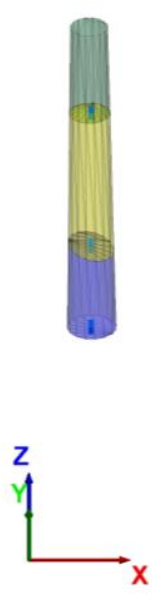

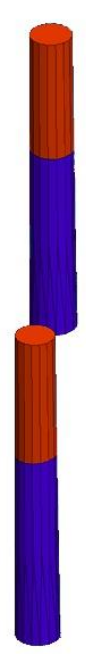

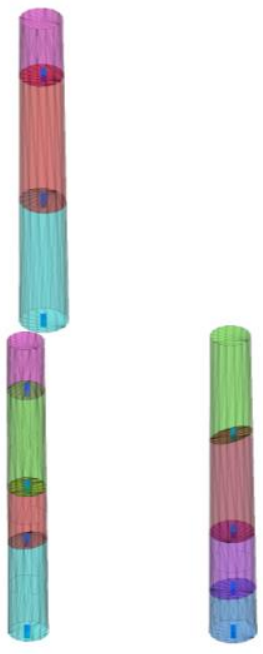

(c)
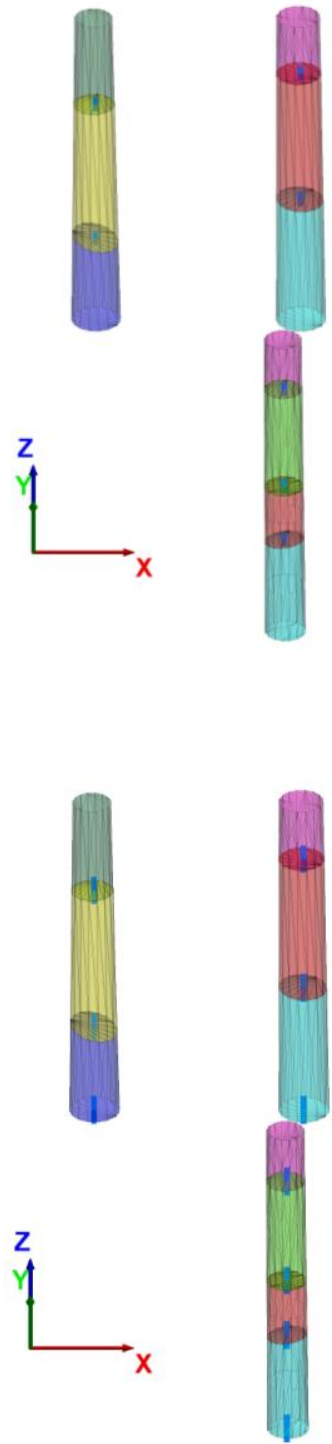

(b)
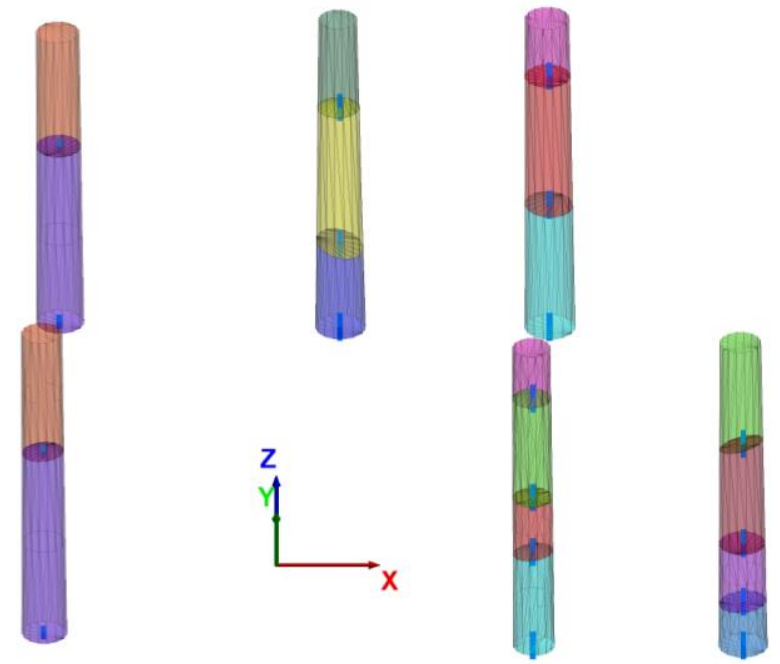

(d)

Figure 7. 3DEC DEM models of columns: (a) model A; (b) model B; (c) model C; (d) model D. Base block is hidden to improve clarity.

\subsection{Seismic Assessment of Reassembled Configurations}

The results of the 16 time-history analyses were processed, for significant nodes such as centroids and their top projections, in terms of displacement vs. time (Figure 8a,c,e,g) and $\mathrm{X}$ displacement vs. Y displacement (Figure $8 \mathrm{~b}, \mathrm{~d}, \mathrm{f}, \mathrm{h}$ ) graphs. The former allowed the control of the behavior of the block elements (e.g., rocking, sliding), while the latter was used to check the displacement of centroids with respect to the base shapes. 

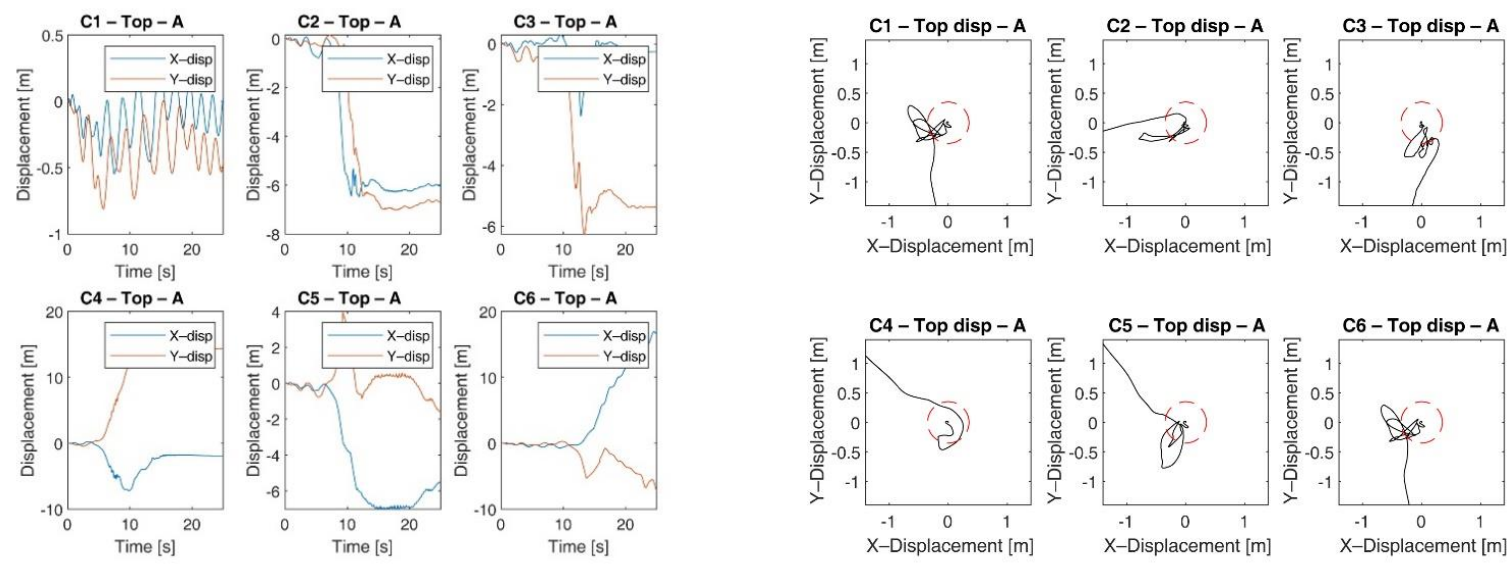

(a)
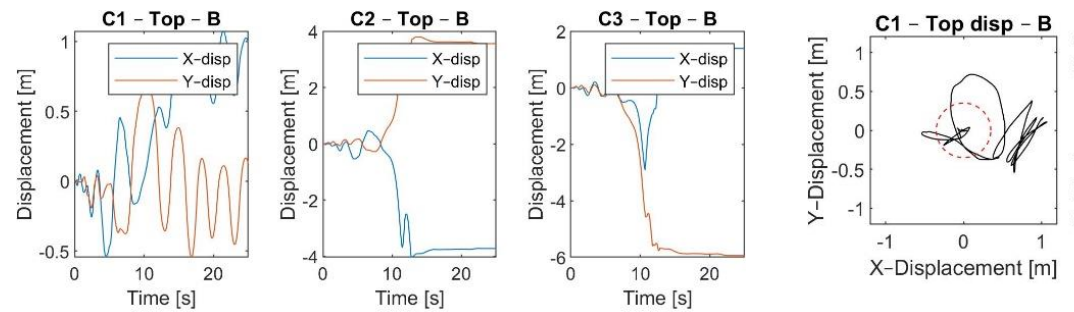

(b)
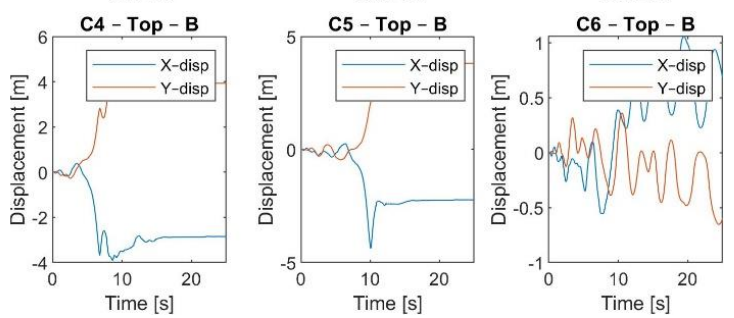

(c)
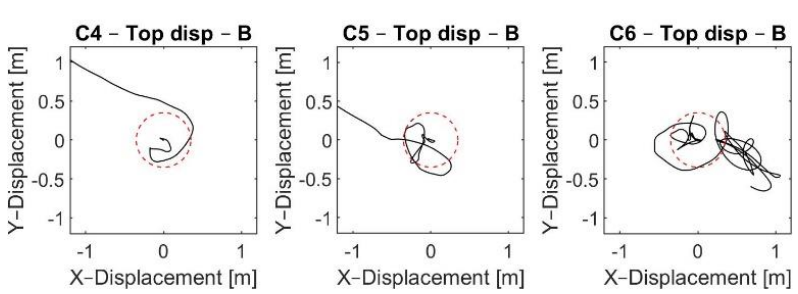

(d)
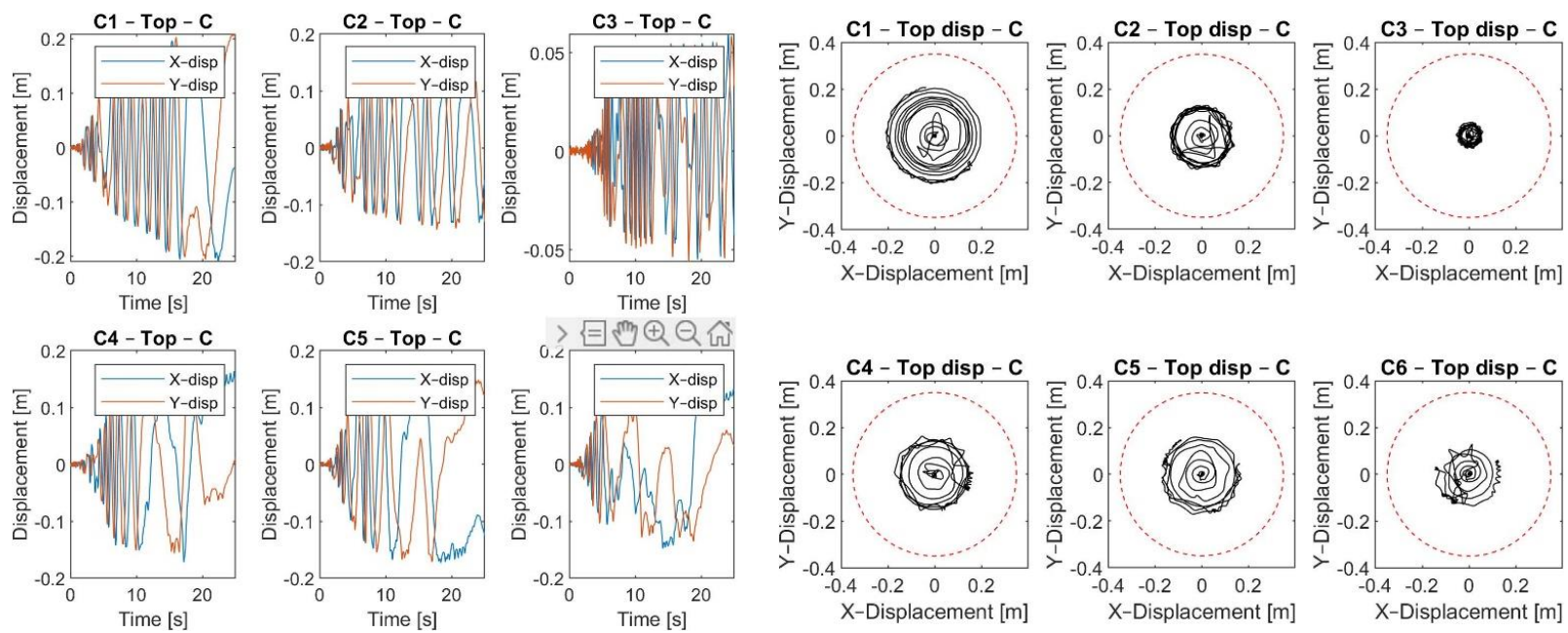

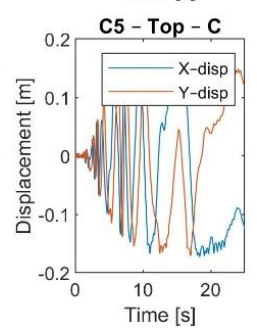

(e)
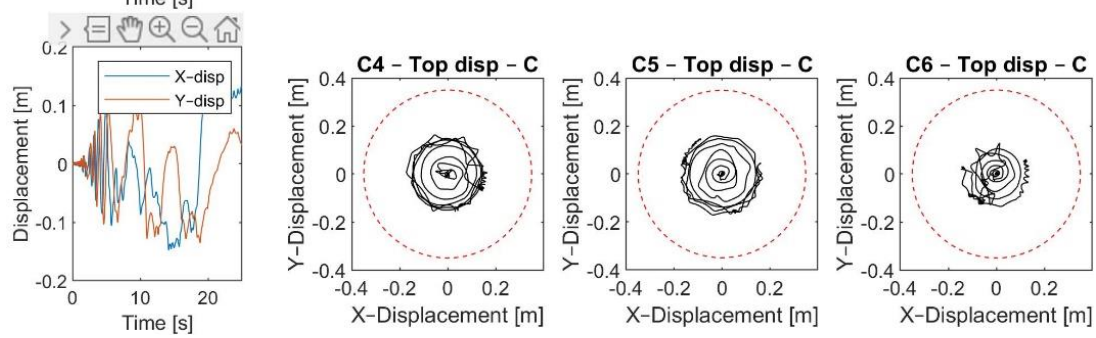

Figure 8. Cont. 

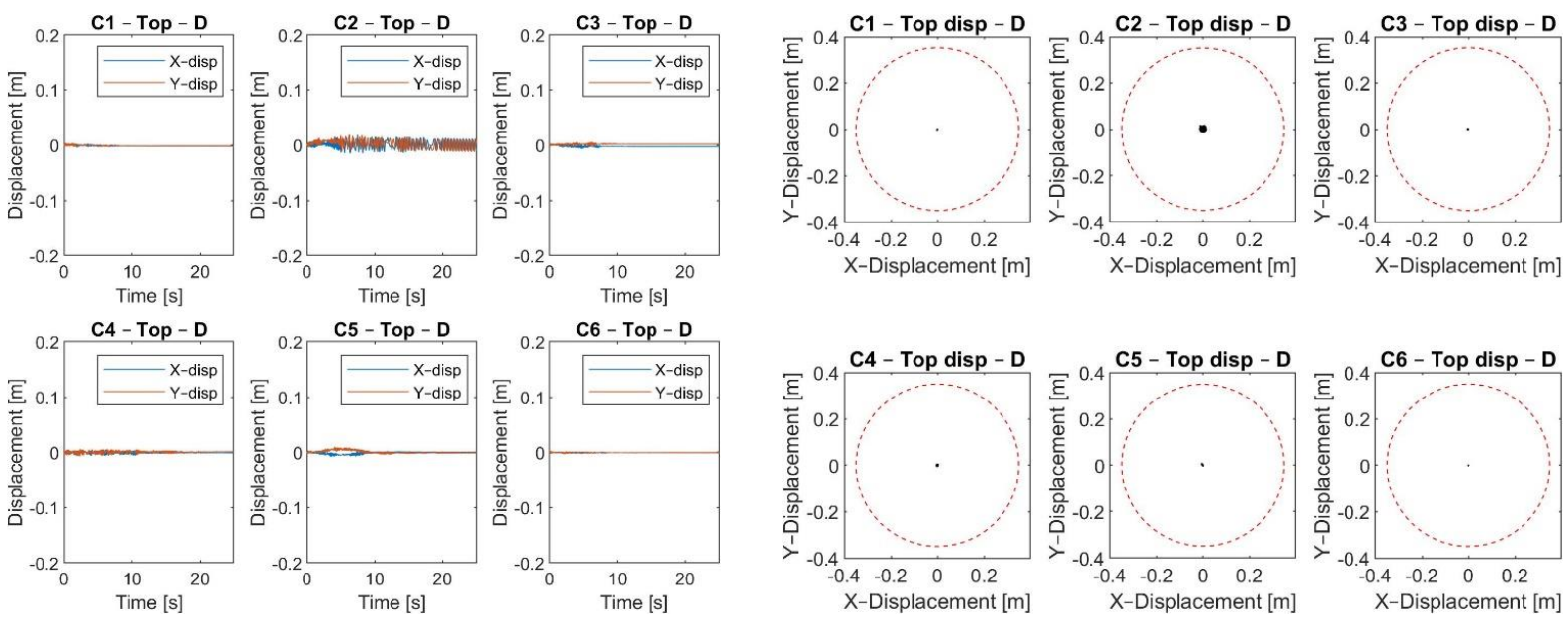

(g)

(h)

Figure 8. Displacement vs. time curves for models (a) A; (c) B; (e) C; (g) D; top centroids displacements (black line) against base shape (red dotted line) for models (b) A; (d) B; (f) C; (h) D.

\section{Discussion}

The results of the 3D dynamic analyses implemented for the four model configurations are discussed below.

Figure $8 \mathrm{a}, \mathrm{b}$ shows the dynamic behavior of model A. Rocking phenomena were initially detected, but, as expected, all columns collapsed.

Figure $8 \mathrm{c}, \mathrm{d}$ shows the dynamic behavior of model B. The use of connectors between blocks increased the equilibrium capacity of the columns that exhibited rocking behavior (Figure 8c). Two out of six columns (No. 1 and 6) still stood after the shocks. However, this condition is not safe, since a noticeable sliding effect was recorded.

Figure 8e,f shows the dynamic behavior of model C. The links of columns to the bases caused the displacement phenomena to decrease, meaning that all columns still stood at the end of the analyses. The connections to the ground generated considerable seismic forces within the titanium bars at the bases (where the highest increases occurred) and, correspondingly, along the other elements until the top of the columns. Although the base displacements were not great enough to exceed base shapes, axial reinforcements overcame axial and shear resistances, and paste-stone interfaces were damaged. A solution to the anastylosis structural problem has been found, but one should accept that damage may occur, and connectors would need repair.

Figure $8 \mathrm{~g}, \mathrm{~h}$ shows the dynamic behavior of model $\mathrm{D}$. The doubling of the titanium bar length and diameter induced a further reduction in the top displacements of the columns. Moreover, axial forces of reinforcements did not exceed yielding stresses, meaning that connectors remained in their elastic phase. This occurred for all the four sets analyzed. This solution can be considered suitable for a configuration that is able to face the expected seismic action in Gortyn with no significant damage to the standing columns.

Figure 9 shows the final configurations of the four models applied to the whole reassembled colonnade. Model A (Figure 9a) reports collapsed elements lying on the ground in a random way (this is also due to the absence of viscous damping, which allows the bouncing of blocks after collapse). The addition of connectors between blocks (Model B; Figure $9 \mathrm{~b}$ ) governs the collapse of columns, which are still bounded during overturning and separate only during the impact with the ground.

Once columns are connected to the ground, rocking displacements are limited (Model C, D; Figure 9c,d). In the case of $40 \mathrm{~cm}$ long bars (Model D), the final layout is almost indistinguishable from the presumed initial conditions. 


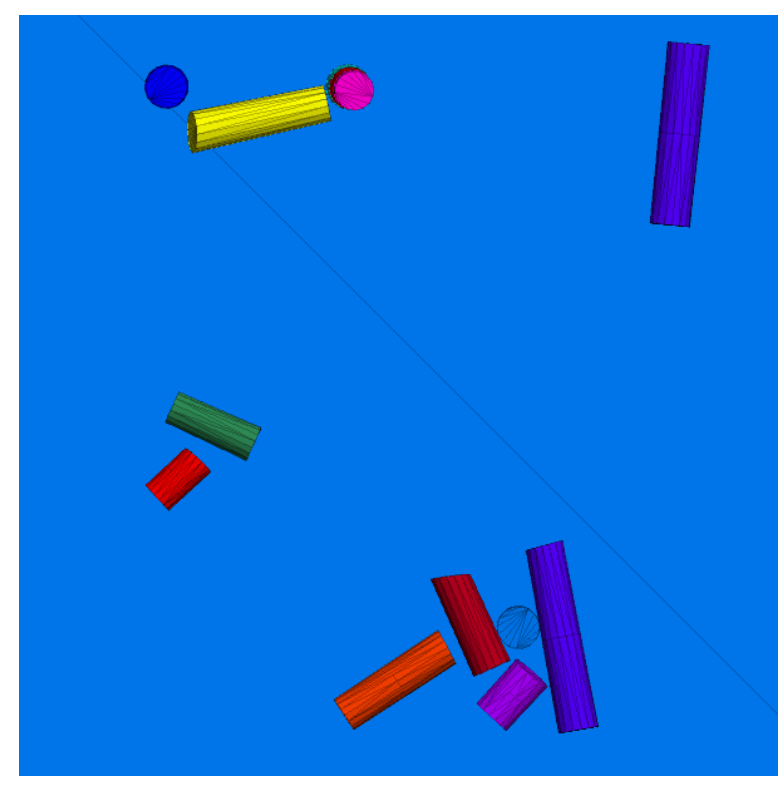

(a)

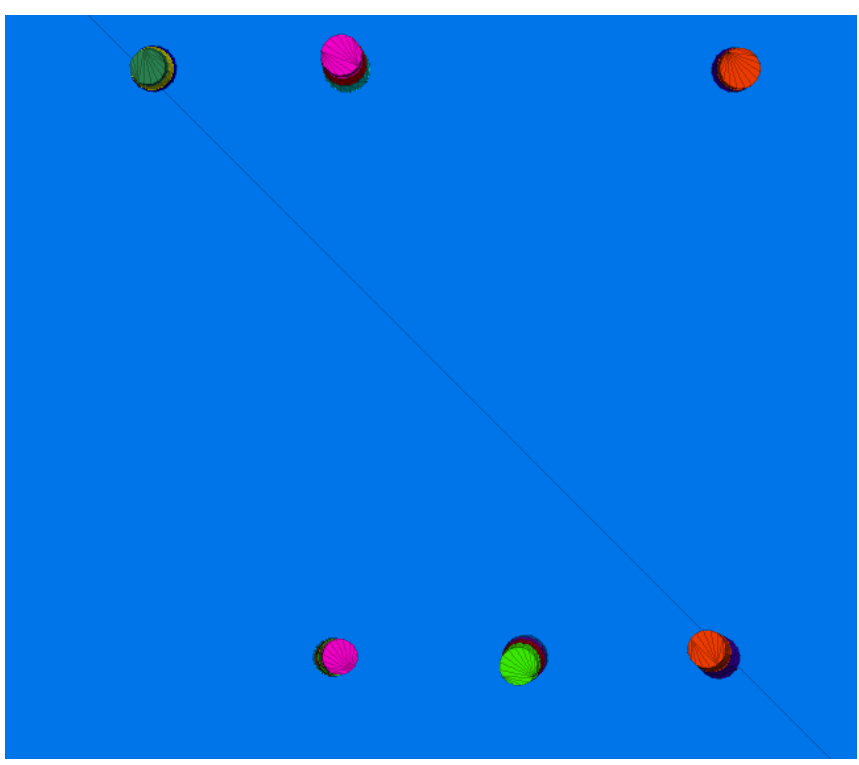

(c)

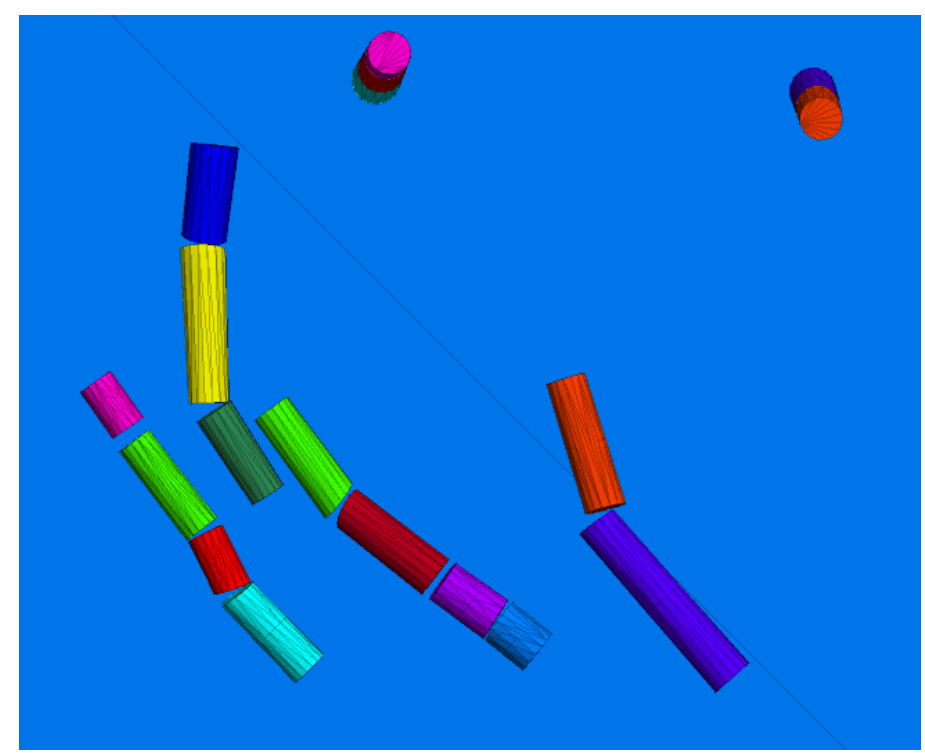

(b)

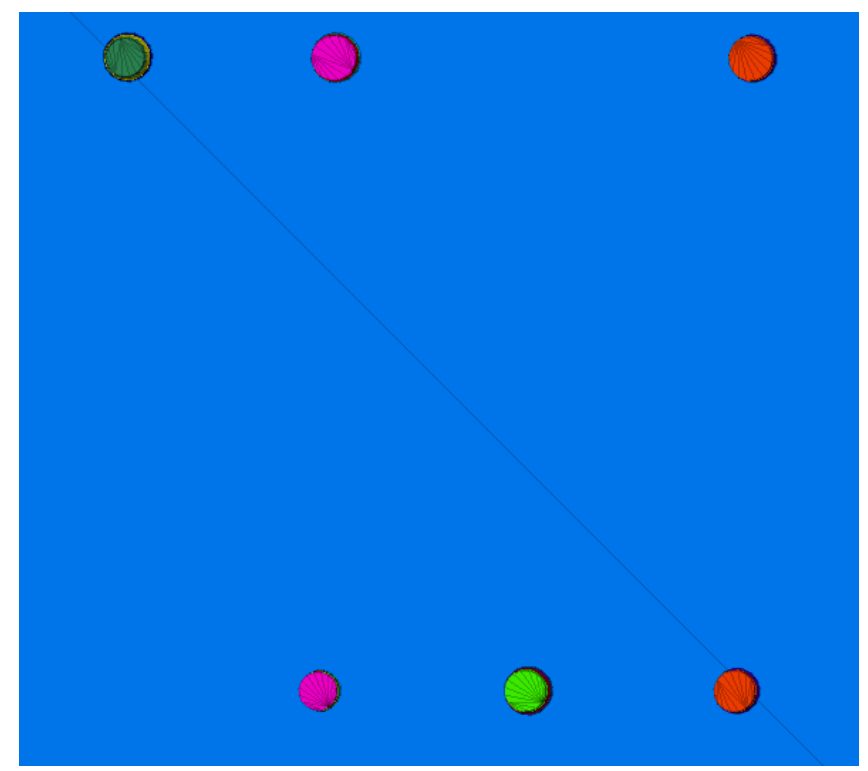

(d)

Figure 9. Top view of final configurations of reassembled colonnade: (a) model A; (b) model B; (c) model C; (d) model D. Blue ground block in background.

\section{Conclusions}

This work presented a multi-disciplinary approach to optimize archaeological studies, engineering procedures and restoration criteria to support the proposal of an anastylosis model for the fragmented columns of the Temple of Apollo Pythios in Gortyn. This procedure allowed the proposal of a preliminary anastylosis model of six out of eight columns, which were recomposed with all the fragmented elements lying on the ground of the temple. Based on data from similar contexts and according to restoration criteria, a possible intervention consisting of threaded titanium connectors embedded with lime-cement paste applied to adjacent fragments of the recomposed columns was designed and validated through dynamic analyses and incremental seismic simulations on a 3D DEM model (from the minimum intervention towards the identification of the first safe solution). 
The connection to the base was revealed to be a key factor for the case of slender and fragmented free-standing columns, such as those of the Temple of Apollo. The presence of connections among the fragments made the columns behave as pseudo-monolithic elements, but this also enhanced the rocking phenomena until collapse (according to the conservative no-viscous damping assumption). The addition of base connections inhibited this phenomenon, but it changed the problem from a pure equilibrium assessment to a hybrid equilibrium-resistance analysis, where connectors must be properly sized to bear seismic loads. Two solutions, with $20 \mathrm{~cm}$ and $40 \mathrm{~cm}$ long titanium bars, were analyzed. The former lead to equilibrium, with the damage of connectors and the possible need of repair in case of the expected seism; the latter allowed damage to be avoided, as longer connectors remained in their elastic phases.

Further developments of this study may concern the implementation of experimental results on materials and the numerical comparison with alternative solutions (e.g., specific connectors per joint/material characteristics, the increase of the connector number instead of their size, the effect of viscous damping). This study could also support the extension of the reassembly, or possible reconstruction, of other elements of the Temple of Apollo.

Author Contributions: Conceptualization and methodology, J.B., M.R.V., M.S., M.Z.; software and formal analysis M.S.; validation, M.S., M.R.V., J.B.; investigation, J.B., M.Z.; resources, J.B., M.R.V.; data curation, M.S., J.B; writing-original draft preparation, M.S.; writing-review and editing, M.R.V., J.B.; visualization, M.S.; supervision, M.R.V.; project administration and funding acquisition, J.B. All authors have read and agreed to the published version of the manuscript.

Funding: This research was funded by Ministero degli Affari Esteri e della Cooperazione Internazionale: University of Padova.

Data Availability Statement: All the resulting data are contained in this article.

Acknowledgments: Italian Archaeological School of Athens; Ephorate of Antiquities of Heraklion (Greece).

Conflicts of Interest: The authors declare no conflict of interest.

\section{References}

1. Ambraseys, N.N. Earthquakes and archaeology. J. Archaeol. Sci. 2006, 33, 1008-1016. [CrossRef]

2. Lorenzoni, F.; Valluzzi, M.R.; Modena, C. Seismic assessment and numerical modelling of the Sarno Baths, Pompeii. J. Cult. Herit. 2019, 40, 288-298. [CrossRef]

3. Bouras, C.; Iannidou, M.; Jenkins, I. (Eds.) Acropolis Restored; The British Museum: London, UK, 2011.

4. Papadopoulos, K.; Vayas, I. Restoration and Strengthening Techniques for Ancient-Greek Monuments. Int. J. Archit. Herit. 2019, 13, 33-46. [CrossRef]

5. Bouras, C. Current Problems of Restoration on the Acropolis. In Acropolis Restoration: The CCAM Interventions; Economakis, R., Ed.; Academy Editions Ltd.: London, UK, 1994.

6. Canciani, M.; Falcolini, C.; Buonfiglio, M.; Pergola, S.; Saccone, M.; Mammì, B.; Romito, G. A method for virtual Anastylosis: The case of the arch of Titus at the circus Maximus in Rome. ISPRS Ann. Photogramm. Remote Sens. Spat. Inf. Sci. 2013, 2, 67-72. [CrossRef]

7. De Luca, L.; Driscu, T.; Peyrols, E.; Labrosse, D.; Berthelot, M. A complete methodology for the virtual assembling of dismounted historic buildings. Int. J. Interact. Des. Manuf. 2014, 8, 265-276. [CrossRef]

8. Heyman, J. The stone skeleton. Int. J. Solids Struct. 1966, 2, 249-279. [CrossRef]

9. Portioli, F.; Casapulla, C.; Gilbert, M.; Cascini, L. Limit analysis of 3D masonry block structures with non-associative frictional joints using cone programming. Comput. Struct. 2014, 143, 108-121. [CrossRef]

10. Portioli, F.; Cascini, L. Contact Dynamics of Masonry Block Structures Using Mathematical Programming. J. Earthq. Eng. 2018, 22, 94-125. [CrossRef]

11. Block, P.; Ochsendorf, J. Thrust network analysis: A new methodology for three-dimensional equilibrium. J. Int. Assoc. Shell Spat. Struct. 2007, 48, 167-173.

12. Olivieri, C.; Angelillo, M.; Gesualdo, A.; Iannuzzo, A.; Fortunato, A. Parametric design of purely compressed shells. Mech. Mater. 2021, 155, 103782. [CrossRef]

13. Angelillo, M.; Olivieri, C.; DeJong, M.J. A new equilibrium solution for masonry spiral stairs. Eng. Struct. 2021, 238, 112176. [CrossRef]

14. Cundall, P.A.; Strack, O.D.L. A discrete numerical model for granular assemblies. Géotechnique 1979, 29, 47-65. [CrossRef] 
15. Jean, M. The non-smooth contact dynamics method. Comput. Methods Appl. Mech. Eng. 1999, 177, 235-257. [CrossRef]

16. Lemos, J.V. Discrete element modelling of the seismic behaviour of stone masonry arches. Comput. Methods Struct. Mason. 1998, $4,220-227$.

17. Lemos, J.V. Discrete Element Modeling of Masonry Structures. Int. J. Archit. Herit. 2007, 1, 190-213. [CrossRef]

18. Chetouane, B.; Dubois, F.; Vinches, M.; Bohatier, C. NSCD discrete element method for modelling masonry structures. Int. J. Numer. Methods Eng. 2005, 64, 65-94. [CrossRef]

19. Clementi, F.; Ferrante, A.; Giordano, E.; Dubois, F.; Lenci, S. Damage Assessment of Ancient Masonry Churches Stroked by the Central Italy Earthquakes of 2016 by the Non-Smooth Contact Dynamics Method; Springer: Dordrecht, The Netherlands, 2020; Volume 18, ISBN 0123456789.

20. Meriggi, P.; De Felice, G.; De Santis, S.; Gobbin, F.; Mordanova, A.; Pantò, B.; Meriggi, P.; De Felice, G.; De Santis, S.; Gobbin, F.; et al. Distinct Element Modelling of Masonry Walls under Out-Of-Plane Seismic Loading Distinct Element Modelling of Masonry Walls under Out-Of-Plane Seismic. Int. J. Archit. Herit. 2019, 13, 1110-1123. [CrossRef]

21. Bui, T.T.; Limam, A.; Sarhosis, V.; Hjiaj, M. Discrete element modelling of the in-plane and out-of-plane behaviour of dry-joint masonry wall constructions. Eng. Struct. 2017, 136, 277-294. [CrossRef]

22. Mendes, N.; Zanotti, S.; Lemos, J.V. Seismic Performance of Historical Buildings Based on Discrete Element Method: An Adobe Church Element Method: An Adobe Church. J. Earthq. Eng. 2018, 24, 1-20. [CrossRef]

23. Saygili, Ö.; Lemos, J.V. Investigation of the structural dynamic behavior of the Frontinus Gate. Appl. Sci. 2020, 10, 5821. [CrossRef]

24. Gonen, S.; Pulatsu, B.; Erdogmus, E.; Karaesmen, E.; Karaesmen, E. Quasi-static nonlinear seismic assessment of a fourth century A.D. Roman Aqueduct in Istanbul, Turkey. Heritage 2021, 4, 401-421. [CrossRef]

25. Housner, G.W. The behavior of inverted pendulum structures during earthquakes. Bull. Seismol. Soc. Am. 1963, 53, 403-417. [CrossRef]

26. Peña, F.; Prieto, F.; Lourenço, P.B.; Campos Costa, A.; Lemos, J.V. On the dynamics of rocking motion of single rigid-block structures. Earthq. Eng. Struct. Dyn. 2007, 36, 2383-2399. [CrossRef]

27. Kim, J.; Lorenzoni, F.; Salvalaggio, M.; Valluzzi, M.R. Seismic vulnerability assessment of free-standing massive masonry columns by the 3D Discrete Element Method. Eng. Struct. 2021, 246, 113004. [CrossRef]

28. Itasca Consulting Group Inc. 3DEC 5.0: 3 Dimensional Distinct Element Code; Itasca Consulting Group Inc.: Minneapolis, MN, USA, 2016.

29. Papantonopoulos, C.; Psycharis, I.N.; Papastamatiou, D.Y.; Lemos, J.V.; Mouzakis, H.P. Numerical prediction of the earthquake response of classical columns using the distinct element method. Earthq. Eng. Struct. Dyn. 2002, 31, 1699-1717. [CrossRef]

30. Itasca Consulting Group Inc. UDEC 3.1: Universal Distinct Element Code; Itasca Consulting Group Inc.: Minneapolis, MN, USA, 2000.

31. Psycharis, I.N.; Papastamatiou, D.Y.; Alexandris, A.P. Parametric investigation of the stability of classic al columns under harmonic and earthquake excitations. Earthq. Eng. Struct. Dyn. 2000, 29, 1093-1109. [CrossRef]

32. Psycharis, I.N.; Fragiadakis, M.; Stefanou, I. Seismic reliability assessment of classical columns subjected to near-fault ground motions. Earthq. Eng. Struct. Dyn. 2013, 42, 2061-2079. [CrossRef]

33. Psycharis, I.N.; Lemos, J.V.; Papastamatiou, D.Y.; Zambas, C. Numerical study of the seismic behaviour of a part of the Parthenon Pronaos. Earthq. Eng. Struct. Dyn. 2003, 2084, 2063-2084. [CrossRef]

34. Ambraseys, N.; Psycharis, I.N. Assessment of the long-term seismicity of Athens from two classical columns. Bull. Earthq. Eng. 2012, 10, 1635-1666. [CrossRef]

35. Sarhosis, V.; Baraldi, D.; Lemos, J.V.; Milani, G. Dynamic behaviour of ancient freestanding multi-drum and monolithic columns subjected to horizontal and vertical excitations. Soil Dyn. Earthq. Eng. 2019, 120, 39-57. [CrossRef]

36. Sincraian, G.E.; Lemos, J.V.; Oliveira, C.S. Assessment of the seismic behavior of stone masonry aqueduct using the discrete element method. In Proceedings of the 11th European Conference on Earthquake Engineering, Paris, France, 6-11 September 1998.

37. Pappas, A.; da Porto, F.; Modena, C.; Dessales, H. Seismic vulnerability assessment of ancient water towers in Pompeii with kinematic, finite element and discrete element analysis. In Proceedings of the 15th Conference Seismic Engineering, Ascoli Piceno, Italy, 30 June-4 July 2013.

38. Pappas, A.; da Porto, F.; Modena, C. Seismic Vulnerability Assessment Form for Free-Standing Columns Based on a Simplified Numerical Analysis. Int. J. Archit. Herit. 2016, 10, 281-299. [CrossRef]

39. Pappas, A.; Sextos, A.; da Porto, F.; Modena, C. Efficiency of alternative intensity measures for the seismic assessment of monolithic free-standing columns. Bull. Earthq. Eng. 2017, 15, 1635-1659. [CrossRef]

40. Autiero, F.; De Martino, G.; Di Ludovico, M.; Mauro, A.; Prota, A. Multidrum Stone Columns at the Pompeii Archaeological Site: Analysis of Geometrical Properties and State of Preservation. Heritage 2020, 3, 1069-1082. [CrossRef]

41. Itasca Consulting Group Inc. 3DEC 5.0: 3 Dimensional Distinct Element Code, Theory and Background; Itasca Consulting Group Inc.: Minneapolis, MN, USA, 2013.

42. Di Vita, A. Gortina di Creta. Quindici Secoli di Vita Urbana; L'erma di Bretschneider: Rome, Italy, 2010.

43. Perna, R. L'acropoli di Gortina. La Tavola "A" della Carta Archeologica della Città; Simple: Macerata, Italy, 2012.

44. Allegro, N.; Santiniello, E. Gortina. L'abitato di Profitis Ilias e la storia più antica della città. In Identità Culturale, Etnicità, Processi di Trasformazione a Creta fra Dark Age e Arcaismo; Rizza, G., Ed.; Università di Catania: Catania, Italy, 2011; pp. 309-322. 
45. La Torre, G. Contributo preliminare alla conoscenza del territorio di Gortina. In Annuario della Scuola archeologica di Atene e delle Missioni Italiane in Oriente, LXVI-LXVII; L'erma di Bretschneider: Rome, Italy, 1989; pp. 277-322.

46. Bonetto, J.; Bertelli, A.; Brombin, E. Excavations in the Sanctuary of Apollo Pythios at Gortyn (Crete): An update. In Proceedings of the Archaeological Work in Crete 5, Proceedings of the 5rd Meeting, Rethymnon, Greece, 22-24 November 2019; Karanastasi, P., Tzigounaki, A., Tsigonaki, C., Eds.;

47. Ricciardi, M. Il tempio di Apollo Pizio a Gortina. In Annuario della Scuola Archeologica di Atene e delle Missioni Italiane in Oriente; LXIV/LXV, 1986/1987; L'erma di Bretschneider: Rome, Italy, 1987; pp. 1-541.

48. Metelli, M.C. Gli Interventi di età Romana nel Tempio di Apollo Pythios a Gortina: Nuove Ricerche e Nuove Ipotesi. Master's Thesis, University of Padova, Padua, Italy, 2015.

49. Bonetto, J. Architetti greci arcaici: Unità di misura e progetto del Tempio di Apollo Pythios a Gortyna di Creta. In I Mille Volti del Passato. Studi in Onore di Francesca Ghedini; Bonetto, J., Busana, M.S., Ghiotto, A.R., Salvadori, M., Zanovello, P., Eds.; Quasar: Rome, Italy, 2016; pp. 521-566.

50. Allegro, N.; Ricciardi, M.; Garraffo, S.; Papadoulos, J.; Gortina, I.V. Le fortificazioni di età ellenistica. In Monografie della Scuola Archeologica di Atene e delle Missioni Italiane in Oriente, X; Aldo Ausilio: Padova, Italy, 1999.

51. Bonetto, J.; Bertelli, A.; Brombin, E. The transformation of the sanctuary of Apollo Pythios at Gortyna in the Hellenistic period. In Annuario della Scuola Archeologica di Atene e delle Missioni Italiane in Oriente, Supplemento 8; Cantilena, R., Carbone, F., Eds.; SAIA: Athens, Greece, 2020; pp. 77-85.

52. Lippolis, E. Restauro e reimpiego nelle poleis della Grecia: Esempi e forme di una prassi negata. In Selinunte: Restauri Dell'antico; De Luca Editori d'Arte: Rome, Italy, 2016; pp. 329-353.

53. Lippolis, E. Roman Gortyn: From Greek polis to provincial capital. In Roman Crete. New Perspectives; Francis, J.E., Kouremenos, A., Eds.; Oxbow Books: Oxford, UK; Philadelphia, PA, USA, 2016; pp. 155-174.

54. Halbherr, F. Relazione sugli scavi del tempio di Apollo Pythio in Gortyna. In Monumenti Antichi pubblicati dall'Accademia dei Lincei, I; 1890; pp. 9-76.

55. Gortina. IX, Teatro del Pythion. Scavi e Ricerche 2001-2013. In Monografie della Scuola Archeologica di Atene e delle Missioni italiane in Oriente XXVIII; Bonetto, J.; Francisci, D.; Mazzochin, S. (Eds.) SAIA: Athens, Greece, 2019.

56. Sanders, I.F. Roman Crete: An Archaeological Survey and Gazetteer of Late Hellenistic, Roman and Early Byzantine Crete; Cambridge University Press: Cambridge, UK, 1982.

57. Marson, C.; da Porto, F.; Modena, C.; Bonetto, J.; Bertelli, A.C. L'edificio scenico del Teatro del Pythion. Lo studio delle evidenze archeologiche per la ricostruzione del sistema strut-turale e per la comprensione dei meccanismi di danno sismico. In Gortina IX. Il Teatro del Pythion. Scavi e Ricerche 2001-2013, Monografie della Scuola Archeologica di Atene e delle Missioni italiane in Oriente XXVIII; Bonetto, J., Francisci, D., Mazzochin, S., Eds.; SAIA: Athens, Greece, 2019; pp. 543-553.

58. Guarducci, M. (Ed.) Inscriptiones Creticae. IV, Tituli Gortynii; La Libreria Dello Stato: Rome, Italy, 1950.

59. Bonetto, J.; Bernardi, L.; Bertelli, A.; Brombin, E.; Colla, M.; de Scarpis di Vianino, V.; Gallucci, G.; Metelli, M.C. Gortyna (Creta). Nuove ricerche presso il santuario di Apollo Pythios (2012-2015). In Annuario della Scuola Archeologica di Atene e delle Missioni Italiane in Oriente XCIV; Italian School of Archaeology at Athens: Athens, Greece, 2016; pp. 37-57.

60. Bertelli, A. Analisi strutturale di un luogo di culto eroico: Il caso dell'Heroon del Pythion di Gortyna. In Proceedings of the Héros Fondateurs et Identités Communautaires dans l'Antiquité, Entre Mythe, Rite et Politique, Grenoble, France, 3-5 May 2017; Quaderni di Otium. Collana di Studi di Archeologia e Antichità Classiche. Castiglioni, M.P., Giuman, R., Carboni, H., Bernier-Farella, H., Eds.; Morpacchi U.P.: Perugia, Italy, 2018; pp. 111-135.

61. Bonetto, J.; Bertelli, A.; Brombin, E.; Colla, M.; de Scarpis di Vianino, V.; Metelli, M.C. New perspectives on the evolution of the sanctuary of Apollo Pythios in Gortyn. In Proceedings of the 4th International Conference, Rethymno, Greece, 24-27 November 2016; pp. 451-466.

62. Guidoboni, E.; Comastri, A.; Traina, G. Catalogue of Ancient Earthquakes in the Mediterranean Area up to the 10th Century; Istituto Nazionale di Geofisica: Rome, Italy, 1994; ISBN 88-85213-06-5.

63. Guidoboni, E.; Comastri, A. Catalogue of Earthquakes and Tsunamis in the Mediterranean Area from the 11th to the 15th Century; National Institute of Geophysics and Vulcanology: Rome, Italy, 2005; ISBN 88-85213-10-3.

64. Di Vita, A. I terremoti a Gortina in età romana e proto-bizantina. Una nota. In Annuario della Scuola Archeologica di Atene e delle Missioni Italiane in Oriente, LVII-LVIII; L'erma di Bretschneider: Rome, Italy, 1980; pp. 435-440.

65. Pirazzoli, P.A.; Ausseil-Badie, J.; Giresse, P.; Hadjiaki, E.; Arnold, M. Historical environmental changes at Phalasarna Harbor, West Crete. Geoarchaeology 1992, 7, 371-392. [CrossRef]

66. Stiros, S.C. The 8.5+ magnitude, AD365 earthquake in Crete: Coastal uplift, topography changes, archaeological and historical signature. Quat. Int. 2010, 216, 54-63. [CrossRef]

67. Ambraseys, N.N.; Melville, C.P.; Adams, R.D. The Seismicity of Egypt, Arabia and the Red Sea: A Historical Review; Cambridge University Press: Cambridge, UK, 1994.

68. En, B.S. Eurocode 8-Design of structures for earthquake resistance. Dict. Geotech. Eng. Geotech. 2014, 3, 486. [CrossRef]

69. Greek Code for Seismic Resistant Structures; Ministry of Environment Planning and Public Works: Athens, Greece, 2003.

70. SeismoSoft SeismoArtif 2016. Available online: https://civilnode.com/download-software/10176646471110/seismosoftseismoartif-2016-r1 (accessed on 10 August 2021). 
71. Papadopoulos, K.; Vintzileou, E. New Titanium Connectors for the Columns Capitals of the Classical Temple of Apollo Epikourios. Int. J. Archit. Herit. 2016, 10, 749-765. [CrossRef]

72. ASTM B348. Standard Specification for Titanium and Titanium Alloy Bars and Billets; ASTM International: West Conshohocken, PA, USA, 2013.

73. Stefanou, I.; Psycharis, I.; Georgopoulos, I.O. Dynamic response of reinforced masonry columns in classical monuments. Constr. Build. Mater. 2011, 25, 4325-4337. [CrossRef]

74. Dakanali, I.; Stavrakas, I.; Triantis, D.; Kourkoulis, S.K. Pull-out of threaded reinforcing bars from marble blocks. Procedia Struct. Integr. 2016, 2, 2865-2872. [CrossRef]

75. Comité Européen de Normalisation. EN 998-2 Specification for Mortar for Masonry. Masonry Mortar; Comité Européen de Normalisation: Brussels, Belgium, 2016.

76. Dasiou, M.E.; Psycharis, I.N.; Vrouva, A. Numerical investigation of the seismic behaviour of connections of ancient colonnades. In Proceedings of the ECCOMAS Thematic Conference-COMPDYN 2011: 3rd International Conference on Computational Methods in Structural Dynamics and Earthquake Engineering: An IACM Special Interest Conference, Programme, Corfu, Greece, 25-28 May 2011; pp. 25-28.

77. Vasconcelos, G.; Lourenço, P.B. Experimental characterization of stone masonry in shear and compression. Constr. Build. Mater. 2009, 23, 3337-3345. [CrossRef]

78. DeJong, M.J. Seismic Assessment Strategies for Masonry Structures. Ph.D. Thesis, Massachusetts Institute of Technology, Cambridge, MA, USA, 2009.

79. Pensabene, P.; Lazzarini, L. Marmi, pietre colorate e maestranze a Creta in età imperiale, in Creta romana e protobizantina. In Proceedings of the Atti del Congresso Internazionale, Iraklion, Greece, 23-30 September 2000; Volume III.1, pp. 763-785. 